\title{
Resistance to the SDHI Fungicides Boscalid and Fluopyram in Podosphaera xanthii Populations from Commercial Cucurbit Fields in Spain
}

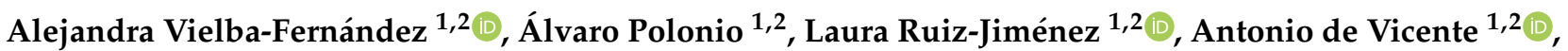 \\ Alejandro Pérez-García ${ }^{1,2}$ and Dolores Fernández-Ortuño $1,2, *$ (D) \\ 1 Departamento de Microbiología, Facultad de Ciencias, Universidad de Málaga, 29071 Málaga, Spain; \\ avielba@uma.es (A.V.-F.); polonio@uma.es (Á.P.); laura110493@uma.es (L.R.-J.); adevicente@uma.es (A.d.V.); \\ aperez@uma.es (A.P.-G.) \\ 2 Instituto de Hortofruticultura Subtropical y Mediterránea "La Mayora", Departamento de Microbiología, \\ Campus de Teatinos, Universidad de Málaga-Consejo Superior de Investigaciones Científicas (IHSM-UMA-CSIC), \\ 29071 Málaga, Spain \\ * Correspondence: dfernandez-ortuno@uma.es
}

check for updates

Citation: Vielba-Fernández, A.; Polonio, Á.; Ruiz-Jiménez, L.; de Vicente, A.; Pérez-García, A.; Fernández-Ortuño, D. Resistance to the SDHI Fungicides Boscalid and Fluopyram in Podosphaera xanthii Populations from Commercial Cucurbit Fields in Spain. J. Fungi 2021, 7, 733. https://doi.org/ 10.3390/jof7090733

Academic Editors: Antonieta De Cal, Inmaculada Larena and Paloma Melgarejo

Received: 14 August 2021

Accepted: 6 September 2021

Published: 8 September 2021

Publisher's Note: MDPI stays neutral with regard to jurisdictional claims in published maps and institutional affiliations.

Copyright: (c) 2021 by the authors. Licensee MDPI, Basel, Switzerland. This article is an open access article distributed under the terms and conditions of the Creative Commons Attribution (CC BY) license (https:/ / creativecommons.org/licenses/by/ $4.0 /)$.

\begin{abstract}
Powdery mildew is caused by Podosphaera xanthii, and is one of the most important diseases that attacks Spanish cucurbit crops. Fungicide application is the primary control tool; however, its effectiveness is hampered by the rapid development of resistance to these compounds. In this study, the $\mathrm{EC}_{50}$ values of 26 isolates were determined in response to the succinate dehydrogenase inhibitor (SDHI) fungicides boscalid and fluopyram. From these data, the discriminatory doses were deduced and used for SDHI resistance monitoring during the 2018 and 2019 growing seasons. Of the 298 isolates analysed, $37.9 \%$ showed resistance to boscalid and $44 \%$ to fluopyram. Although different phenotypes were observed in leaf disc assays, the resistant isolates showed the same phenotype in plant assays. Compared to sensitive isolates, two amino acid changes were found in the SdhC subunit, A86V and G151R, which are associated mostly with resistance patterns to fluopyram and boscalid, respectively. Furthermore, no significant differences were observed in terms of fitness cost between the selected sensitive and resistant isolates analysed here. Lastly, a loop-mediated isothermal amplification (LAMP) assay was developed to detect A86V and G151R mutations using conidia obtained directly from infected material. Our results show that growers could continue to use boscalid and fluopyram, but resistance management practices must be implemented.
\end{abstract}

Keywords: SDHI resistance; boscalid; fluopyram; disease control; fitness cost; fungicide resistance; powdery mildew; resistance development; resistance management; LAMP

\section{Introduction}

Cucurbits are very important crops in Spanish agriculture. Within the vegetable sector, annual cucurbit production reached 3 million tons and yielded revenues of more than $€ 1.9$ billion in 2018 [1]. One of the most destructive diseases that affect these crops is powdery mildew, which is an important limiting factor for cucurbit production in Spain $[2,3]$. This disease can be caused by the biotrophic fungal species Podosphaera xanthii (Fr.) U Braun \& N Shishkoff or Golovinomyces cichoracearum (DC.) VP Galut, [4], but in Spain, only P. xanthii has been detected over the last three decades [5-10]. Despite the substantial efforts that have been invested in plant breeding programs to combat powdery mildew disease, chemical control continues to be the principal practice for managing most cucurbit crops; however, it has been hampered by the emergence of resistant populations in the field soon after the introduction of certain classes of site-specific fungicides. In southern Spain, resistance to the most popular anti-powdery mildew fungicides, such as quinone outside inhibitors (QoIs), demethylation inhibitors (DMIs) and methyl benzimidazole carbamate 
(MBC) fungicides, has been reported [7-11]. More importantly, multiresistant isolates have been found in several areas of more intense cropping [9].

Succinate dehydrogenase inhibitors (SDHIs; FRAC group 7) have been on the market for more than 40 years, and are within the class with the fastest growth in terms of new compounds released onto the market. To date, twenty-three SDHI active ingredients belonging to 11 chemical classes with a broader spectrum of fungal activity have been offered for fungal plant pathogen control [12]. SDHI fungicides have a single-site mode of action, inhibiting the fungal respiration pathway by binding the ubiquinone binding site of succinate dehydrogenase (SDH; also known as complex II) and blocking mitochondrial electron transfer from succinate to ubiquinone [13]. This target protein is formed by four subunits (A, B, C and D), but the ubiquinone-binding site only comprises amino acids from subunits B (SdhB), C (SdhC), and D (SdhD; [14]).

SDHIs are classified as medium to high risk for resistance development. Therefore, it is not surprising that resistance to these fungicides has been documented since shortly after their registration for use against several phytopathogenic fungi [15]. More than 40 point mutations in SdhB, SdhC and SdhD have been linked to reduced sensitivity to SDHIs. In SdhB, the changes H272L/R/T and H277L/R/Y are the most common, having been described in several fungal plant pathogens, such as Alternaria alternata [16-21], Botrytis cinerea [22-27], B. elliptica [28], Didymella bryionidae [29], P. xanthii [30], Pyrenophora teres [31] and Sclerotinia sclerotiorum [28]. Notably, the amino acid changes H133R in SdhC and D124E/N and H133P/R in SdhD have been found in pathogens such as A. alternata [16-21], A. solani [32], B. cinerea [22], P. xanthii [33], P. teres [31] and S. sclerotiorum [28]. Although these amino acid changes are the most commonly described, other changes in the subunits SdhB (P225F/H/L/T, P230A/D/F/I/R, N230I, N235D/E/G/T and T268I), SdhC (S73P, N75S, G79R, T79N, W80S, A86V, N86S, G91R, S135R, H146R, G150R, H151R, V166M and G172D) and SdhD (A47T, S89P, G109V, S121P, H137R and D145G) have been documented in several phytopathogenic fungi, generating a pool of point mutations that confer different levels of resistance to the different SDHI fungicides [15].

To avoid field control failure, and for the efficient use of the fungicides that are available on the market, it is important to have good knowledge about the resistance situation in the field. For that reason, the most commonly used methods are based on mycelial growth or conidial germination in vitro assays in culture medium or plant material supplemented with different fungicide concentrations [34]. However, these methods are time consuming, especially when studying biotrophic fungi, and, therefore, molecular methods based on the detection of single-nucleotide polymorphisms are gaining in importance due to their quicker response times. Among the most commonly used approaches are polymerase chain reaction-restriction fragment length polymorphism (PCR-RFLP), allele-specific PCR (AS-PCR), cleaved amplified polymorphic sequences (CAPS) and high-resolution melt (HRM) analysis [16,17,35-39]. Although all these methods are faster than in vitro assays, they require specific equipment that not all laboratories can afford. In recent years, the loop-mediated isothermal amplification (LAMP) technique developed by Notomi and collaborators [40], has become an excellent alternative due to its cost, speed, and accuracy in fungicide resistance monitoring studies [41-44]. This technique, which is based on the combination of the Bst polymerase and four primer pairs, which hybridize with six regions in the target DNA, can amplify the product of interest under isothermal conditions [40]. In addition, the amplification product can be visualized with the naked eye using DNAintercalating reagents such as SYBR-Green I [45], metal-ion indicators such as hydroxy naphthol blue (HNB) [46] or calcein [47], and even pH-sensitive dyes [48]. Recently, the LAMP technique has been successfully used to detect two-point mutations involved in SDHI resistance, namely H272R in SdhB in B. cinerea [49] and the change N75S in the SdhC in C. cassiicola [50].

In Spain, there are seven chemical classes of fungicides (aryl-phenyl-ketones (FRAC group 50), DMI (FRAC group 3), hydroxy-(2-amino-) pyrimidines (FRAC group 8), MBC 
(FRAC group 1), phenyl-acetamide (FRAC group U 06), QoIs (FRAC group 11) and SDHIs) registered for cucurbit powdery mildew control, with SDHI fungicides being one of the most frequently applied classes. Boscalid was the first SDHI registered in 2008, followed by fluopyram (2016), penthiopyrad (2017), isopyrazam (2018) and fluxapyroxad (2019). To date, P. xanthii resistance to SDHIs has not been documented in Spain, but evidence has started to emerge that resistance is developing in commercial cucurbit fields. For this reason, in the current study, cucurbit samples affected by powdery mildew symptoms from the primary cucurbit production areas in south-eastern Spain were collected during the 2018 and 2019 growing seasons. The fungal pathogen was isolated and identified as $P$. xanthii, and its sensitivity to boscalid and fluopyram was characterized using an in vitro leaf-disc bioassay and in planta analysis. The molecular alterations in the target gene subunits (SdhB, SdhC and SdhD) and the possible associated fitness costs were also studied. In addition, a LAMP assay for the rapid and reliable detection of two-point mutations related to $P$. xanthii SDHI resistance in our country was developed.

\section{Materials and Methods}

\subsection{Fungal Isolates}

In total, 26 single-spore isolates of P. xanthii were examined to determine the discriminatory doses for the SDHI fungicides boscalid and fluopyram (Table 1). These isolates were collected from several locations in Spain (Almeria, Badajoz, Ciudad Real, Cordoba, Granada, Malaga, Murcia, and Valencia) during the years 1988-2016, as previously described [7]. For the maintenance of the P. xanthii isolates, conidia were placed on zucchini cotyledons (Curcubita pepo cv. Negro Belleza; Semillas Fitó, Barcelona, Spain) that had previously been disinfected by 10 min of immersion in $5 \%$ sodium hypochlorite and deposited in $5 \mathrm{~cm}$ diameter Petri dishes containing Bertrand agar medium (sucrose $40 \mathrm{~g} / \mathrm{L}$, benzimidazole $0.03 \mathrm{~mL} / \mathrm{L}$, and agar $10 \mathrm{~g} / \mathrm{L}$ in distilled water; [51]). Then, the isolates were maintained at $25^{\circ} \mathrm{C}$ under a $16 \mathrm{~h}$ photoperiod of LED light or stored at $-80^{\circ} \mathrm{C}$ using silica gel for long-term conservation [52].

For SDHI monitoring studies, 298 P. xanthii isolates were collected from 18 fields and greenhouses located in four cucurbit production areas (Almeria, Granada, Malaga, and Murcia) in southeast Spain during the 2018 and 2019 growing seasons. At least 10 leaves affected by powdery mildew symptoms were taken per location. For all samples, singlespore isolation was performed as previously described [7]. The single-spore isolates were identified as $P$. xanthii according to the characteristics of the conidia and maintained at $-80{ }^{\circ} \mathrm{C}[5,52]$.

\subsection{Fungicide Sensitivity Studies for the SDHI Fungicides Boscalid and Fluopyram}

To determine the discriminatory doses for distinguishing SDHI-sensitive from SDHIresistant isolates, a leaf-disc bioassay was conducted with some modifications [7]. In brief, $1 \mathrm{~cm}$ diameter leaf discs from 8 to 10-day-old zucchini cotyledons (Curcubita pepo cv. Negro Belleza; Semillas Fitó, Barcelona, Spain) were cut with a corkborer and incubated upside down for $1 \mathrm{~h}$ on sterile filter paper that had absorbed $3 \mathrm{~mL}$ of sterile distilled water (untreated control) and several concentrations of the two study SDHIs. Five concentrations of boscalid (Cantus, BASF S.L., Ludwigshafen, Germany) and fluopyram (Luna Privilege; Bayer CropScience S.L., Leclair, France) were used at 0.01, 0.1, 1, 10 and $100 \mathrm{mg} / \mathrm{L}$, with the last concentration being the field dose recommended by both manufacturers. Then, the discs were allowed to dry on Bertrand medium and the P. xanthii isolates were inoculated onto their adaxial surface using an eyelash. After 10 days of incubation under the same conditions described above, powdery mildew growth was assessed according to a 0-3 scale with 0 indicating the absence of symptoms and 1, 2 and 3 indicating $<25 \%, 25-50 \%$ and $>50 \%$ of the disc surface covered with fungal mycelial growth, respectively. To calculate the disease severity (DS), the formula $[(0 a+1 b+2 c+3 d) / 3 N] \times 100$ was used, where $a, b, c$, and d correspond to the number of discs of scale value $0,1,2$ and 3, respectively, and $\mathrm{N}$ was the total number of leaf discs assessed $(\mathrm{a}+\mathrm{b}+\mathrm{c}+\mathrm{d})$. Minimal inhibitory 
concentrations (MICs) were deduced directly from the data being the lowest concentration that inhibits the growth of $P$. xanthii after its inoculation. On the other hand, the fungicide concentrations inhibiting $50 \%$ of the powdery mildew growth $\left(\mathrm{EC}_{50}\right)$ were calculated with graphical representation of the log transformation of percentages of inhibition (100-DS) and regression against the logarithm of the fungicide concentration used here [7]. The assay was performed three times.

Table 1. Sensitivity of 26 randomly chosen Podosphaera xanthii isolates to the SDHI fungicides boscalid and fluopyram. The values of the minimal inhibitory concentration (MIC) and concentration inhibiting $50 \%$ of the growth (EC 50 ) are shown.

\begin{tabular}{|c|c|c|c|c|c|c|c|}
\hline \multirow{2}{*}{ Isolate } & \multirow{2}{*}{ Year } & \multirow{2}{*}{ Location } & \multirow{2}{*}{ Host } & \multicolumn{2}{|c|}{ MIC (mg/L) } & \multicolumn{2}{|c|}{$\mathrm{EC}_{50}(\mathrm{mg} / \mathrm{L})$} \\
\hline & & & & Boscalid & Fluopyram & Boscalid & Fluopyram \\
\hline 22014 & 2002 & Almeria & Zucchini & 1 & 0.1 & 0.36 & 0.13 \\
\hline 31430 & 2003 & Murcia & Melon & 10 & 1 & 11.17 & 0.70 \\
\hline 31869 & 2004 & Murcia & Melon & $<10$ & $<10$ & 0.62 & 1.01 \\
\hline 44675 & 2003 & Valencia & Watermelon & $<10$ & 0.1 & 1.78 & 0.04 \\
\hline 64132 & 2002 & Cordoba & Zucchini & $<10$ & 0.1 & 1.10 & 0.66 \\
\hline 71175 & 2002 & Ciudad Real & Melon & $<10$ & $<10$ & 1.27 & 1.66 \\
\hline 72174 & 2002 & Ciudad Real & Zucchini & 10 & 1 & 3.42 & 0.45 \\
\hline 81210 & 2002 & Badajoz & Melon & 1 & 0.1 & 0.03 & $3 \times 10^{-4}$ \\
\hline 221104 & 2006 & Almeria & Zucchini & $<10$ & $<10$ & 1 & 1.91 \\
\hline 311254 & 2008 & Murcia & Melon & 1 & 0.1 & 0.40 & 0.19 \\
\hline 311271 & 2008 & Murcia & Melon & 10 & 0.1 & 2 & 0.77 \\
\hline 711356 & 2008 & Ciudad Real & Melon & 10 & 1 & 1.51 & 0.24 \\
\hline 711419 & 2009 & Ciudad Real & Melon & 1 & 1 & 0.26 & 0.60 \\
\hline 711420 & 2009 & Ciudad Real & Melon & $<10$ & 0.1 & 3.50 & $2 \times 10^{-3}$ \\
\hline 811414 & 2009 & Badajoz & Melon & 1 & 0.1 & 0.54 & $2 \times 10^{-3}$ \\
\hline 811415 & 2009 & Badajoz & Melon & 10 & $<10$ & 5.46 & 4.42 \\
\hline $1502404 \mathrm{~A}$ & 2016 & Almería & Watermelon & 10 & 1 & 5.86 & 0.47 \\
\hline 1503405 C & 2016 & Murcia & Watermelon & 10 & 1 & 2.33 & 0.43 \\
\hline $1509409 \mathrm{C}$ & 2015 & Murcia & Watermelon & 10 & 1 & 1.11 & $1 \times 10^{-4}$ \\
\hline $1513406 \mathrm{C}$ & 2015 & Granada & Watermelon & 10 & 1 & 2.94 & 0.52 \\
\hline $\mathrm{JF}^{\prime \prime} 12$ & 2012 & Ciudad Real & Melon & 1 & 1 & 0.97 & 0.77 \\
\hline JF02'11 & 2011 & Ciudad Real & Melon & 1 & 1 & 0.42 & 0.87 \\
\hline JF06'10 & 2010 & Ciudad Real & Melon & 1 & 1 & 0.24 & 0.55 \\
\hline JF09'11 & 2011 & Ciudad Real & Melon & 1 & 1 & 0.52 & 0.35 \\
\hline JF13'10 & 2010 & Ciudad Real & Melon & 10 & 1 & 0.20 & 0.17 \\
\hline SF9 & 1988 & Malaga & Zucchini & 1 & $<10$ & 0.08 & 2.01 \\
\hline
\end{tabular}

\subsection{In Vivo Fungicide Sensitivity Tests to Boscalid and Fluopyram in Greenhouse Experiments}

For the in vivo fungicide sensitivity assay, a total of 240 melon plants (Cucumis melo cv. Rochet; Semillas Fitó) were raised in seedling trays at a constant temperature $\left(25^{\circ} \mathrm{C}\right)$. A total of 16 P. xanthii isolates, which represented the most frequently found phenotypes observed during the SDHI monitoring studies, were tested: sensitive (S) to boscalid and fluopyram (SF9, 81210 and 18130304A); low resistance (LR) to both fungicides (18020307D); LR to boscalid and moderate resistance (MR) to fluopyram (18020307C); LR to boscalid and resistant (R) to fluopyram (18020307F); MR to both fungicides (18030306D); MR to boscalid and R to fluopyram (18020305L); R to boscalid and MR to fluopyram (18030306Q); R to both fungicides (18130301D, 18020303Q and 18030306H); LR to boscalid and high resistance (HR) to fluopyram (18020307E and 18020307J) and, lastly, R to boscalid and HR to fluopyram (18030306B). The following treatments were performed on each isolate: (i) five untreated plants, (ii) five plants treated with the field label rate of $100 \mathrm{mg} / \mathrm{L}$ boscalid (Cantus) and (iii) five plants treated with the recommended field dose of $100 \mathrm{mg} / \mathrm{L}$ fluopyram (Luna Privilege). The different applications were performed $24 \mathrm{~h}$ before the P. xanthii inoculation was performed. One leaf per plant was then inoculated with each isolate at three equidistant points using a paintbrush. Fifteen days after the inoculation, the development of each P. xanthii isolate on the leaf surface was evaluated. The experiment performed three times. 


\subsection{Determination of Mutations in the $S d h B, S d h C$ and $S d h D$ Genes}

Fragments of the $S d h B, S d h C$ and $S d h D$ genes were searched in the partial transcriptome of the $P$. xanthii haustorium and mapped against the P. xanthii genome with TBLASTN using Blast Plus 2.2.30 and the NCR database of the NCBI in BAST1 with an e-value of $1 \times 10^{-5}$ [53]. Once the sequences were obtained, several pairs of primers were designed, for the first time in P. xanthii, to amplify the open reading frames (ORFs) of the Sdh subunits B (SdhB_Forward/SdhB_reverse), C (SdhC_Forward/SdhC_Reverse), and D (SdhD_Forward/SdhD_Reverse; Table 2). The DNA of nine P. xanthii-sensitive isolates and 66 isolates found to have different levels of resistance to boscalid and fluopyram was extracted using the MasterPureTM Yeast DNA Purification Kit (Lucigen, Middleton, WI, USA). All PCRs were performed with Phusion High-Fidelity DNA Polymerase (Thermo Fisher Scientific, Vilnius, Lithuania) using the following mix: $1 \times$ HF Buffer (Thermo Fisher Scientific), $0.2 \mathrm{mM}$ dNTPs (Bioline, Almería, Spain), $0.2 \mu \mathrm{M}$ primers (Sigma-Aldrich, Taufkirchen, Germany), 0.5 U Phusion High-Fidelity DNA Polymerase (Thermo Fisher Scientific), $1 \mu \mathrm{L}$ of $P$. xanthii DNA (100 ng/ $\mu \mathrm{L})$ and sterile distilled water up to a final volume of $50 \mu \mathrm{L}$. Amplifications were performed in an MJ Mini Thermal Cycler machine (Bio-Rad, Hercules, CA, USA) with an initial denaturation of $98{ }^{\circ} \mathrm{C}$ for $30 \mathrm{~s}$; 35 cycles with three steps (denaturation at $98^{\circ} \mathrm{C}$ for $10 \mathrm{~s}$, hybridization at $61^{\circ} \mathrm{C}$ for the $S d h B$ and $D$ subunits or $65^{\circ} \mathrm{C}$ for $S d h C$ for $30 \mathrm{~s}$; and an extension step at $70^{\circ} \mathrm{C}$ for $20 \mathrm{~s}$ ); and lastly, an elongation step at $72{ }^{\circ} \mathrm{C}$ for $10 \mathrm{~min}$. The amplified fragments were visualized in a $1 \%$ agarose gel stained with RedSafe (iNtRON, Burlington, MA, USA) and purified with a GFX PCR DNA and Gel Band Purification Kit (VWR, Barcelona, Spain). All the amplicons were sequenced by StabVida (Lisbon, Portugal), and the sequences were aligned using DNASTAR 7 computer sequence analysis software.

\subsection{Fitness Assays}

The following fitness components were investigated in six $P$. xanthii isolates that represent the most frequently found SDHI phenotypic groups: S (81210 and 18130304A); LR to boscalid and fluopyram (18020307D); MR to boscalid and R to fluopyram (18030305L); $\mathrm{R}$ to boscalid and fluopyram (18020303Q); and LR to boscalid and HR to fluopyram (18020307J). All the experiments were performed three times.

\subsubsection{Conidial Germination}

Conidial germination was measured at two different temperatures $\left(17\right.$ and $\left.23{ }^{\circ} \mathrm{C}\right)$. The isolates were inoculated by slightly blowing over the adaxial surface of three cucurbit cotyledons in a laminar air flow chamber under sterile conditions. The cotyledons were then deposited in $9 \mathrm{~cm}$ Petri dishes containing Bertrand medium and incubated for 24, 48 and $72 \mathrm{~h}$ in growth chambers with a $16 \mathrm{~h}$ photoperiod and the two temperatures described above. After the incubation period, four leaf discs were cut with an 11-mm diameter cork borer from each cotyledon. The discs were discoloured in boiling $96^{\circ}$ ethanol for $15 \mathrm{~min}$. The discoloured leaf discs were stained by soaking for $5 \mathrm{~min}$ with $150 \mu \mathrm{L}$ of $0.01 \%$ Fluorescent Brightener 28 (Sigma-Aldrich, Burlington, MA, USA). Then, they were examined using a Nikon AZ-100 Multizoom Diascopic Microscope (UV-2A filter, EX 330-380; DM 400; BA 420, Tokyo, Japan). To determine the conidial germination status, ungerminated conidia, germinated conidia with one germination tube, and germinated conidia with two or more germinative tubes were considered [54]. Over 300 conidia per isolate, temperature and time were counted. The data were analysed by two-way ANOVA following Fisher's LSD test $(\alpha \leq 0.05)$, with a confidence interval (CI) of $95 \%$ using the software GraphPad Prism 8 (GraphPad Software, San Diego, CA, USA). Each experiment was carried out three times per isolate and condition. 
Table 2. Primers used in this study.

\begin{tabular}{|c|c|c|c|}
\hline \multicolumn{2}{|c|}{ Primer Name } & Sequence $\left(5^{\prime}-3^{\prime}\right)$ & Description \\
\hline \multicolumn{2}{|c|}{ SdhB_Forward } & GCGGGGAGACCTCTGAGATA & \multirow{2}{*}{$\begin{array}{l}\text { Used to amplify a fragment of 1060-bp which } \\
\text { contains the 886-bp sdhB ORF of } P \text {. xanthii }\end{array}$} \\
\hline \multicolumn{2}{|c|}{ SdhB_Reverse } & GCCAGCAAGGGAGGATGATAA & \\
\hline \multicolumn{2}{|c|}{ SdhC_Forward } & CCAATTCTCGCCGATTTCGC & \multirow{2}{*}{$\begin{array}{l}\text { Used to amplify a fragment of } 1220-\text { bp which } \\
\text { contains the 737-bp sdhC ORF of } P \text {. xanthii }\end{array}$} \\
\hline \multicolumn{2}{|c|}{ SdhC_Reverse } & CCCGCATACCCCTGGTATTC & \\
\hline \multicolumn{2}{|c|}{ SdhD_Forward } & CGGGTAGGTCGCCTTAGTAC & \multirow{2}{*}{$\begin{array}{l}\text { Used to amplify a fragment of 1079-bp which } \\
\text { contains the 695-bp sdhD ORF of P. xanthii }\end{array}$} \\
\hline \multicolumn{2}{|c|}{ SdhD_Reverse } & CGACGTGTCGCATTTGCATT & \\
\hline \multicolumn{4}{|c|}{ LAMP assay } \\
\hline \multirow{4}{*}{ F⿱艹 } & F3 & ATCAACGTGACGACCTGA & \multirow{8}{*}{$\begin{array}{l}\text { Set of primers used in LAMP assays to amplify a } \\
\text { fragment of } 189-\mathrm{bp} \text { of the } S d h C \text { allele coding for } \\
\text { the A86V amino acid change. }\end{array}$} \\
\hline & B3 & CCACCCGATATGACACAG & \\
\hline & FIP & $\begin{array}{c}\text { GGTTCTTACGTTGAGCTATAAGAGTCTCTT } \\
\text { AGACCCGTGACAAC }\end{array}$ & \\
\hline & $\mathrm{BIP}$ & $\begin{array}{c}\text { GTCCCACATCTCCGCATTTACCCCGTAATG } \\
\text { CGATTCAGgA }\end{array}$ & \\
\hline \multirow{4}{*}{ 胥 } & F3 & ATCAACGTGACGACCTGA & \\
\hline & B3 & CCACCCGATATGACACAG & \\
\hline & FIP & $\begin{array}{l}\text { GGTTCTTACGTTGAGCTATAAGAGTTTTTC } \\
\text { TCTTAGACCCGTGACAAC }\end{array}$ & \\
\hline & BIP & $\begin{array}{c}\text { GTCCCACATCTCCGCATTTACTTTTCCCGTA } \\
\text { ATGCGATTCAGgA }{ }^{1}\end{array}$ & \\
\hline \multirow{4}{*}{ 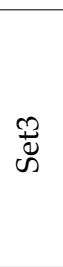 } & F3 & CTAGGATTGAAGTCTCTGGT & \multirow{8}{*}{$\begin{array}{l}\text { Set of primers used in LAMP assays to amplify a } \\
\text { fragment of the 199-bp of the } S d h C \text { allele coding } \\
\text { for the G151R amino acid change. }\end{array}$} \\
\hline & B3 & TTTGTAGAGCCTACGTGATT & \\
\hline & FIP & $\begin{array}{c}\text { TTGAAAAGGCCTTGCCCAAATCCCTTTCAC } \\
\text { TTTTCATTCAATAAAaA }^{1}\end{array}$ & \\
\hline & $\mathrm{BIP}$ & $\begin{array}{c}\text { AGGCAGTTATTAAAACAGGCTGGGTAACCA } \\
\text { AAGCTAATGCACT }\end{array}$ & \\
\hline \multirow{4}{*}{ 莡 } & F3 & CTAGGATTGAAGTCTCTGGT & \\
\hline & B3 & TTTGTAGAGCCTACGTGATT & \\
\hline & FIP & $\begin{array}{c}\text { TTGAAAAGGCCTTGCCCAAATCTTTTCCTT } \\
\text { TCACTTTTCATTCAATAAAaA }{ }^{1}\end{array}$ & \\
\hline & BIP & $\begin{array}{c}\text { AGGCAGTTATTAAAACAGGCTGGTTTTGTA } \\
\text { ACCAAAGCTAATGCACT }\end{array}$ & \\
\hline
\end{tabular}

${ }^{1}$ The nucleotide that hybridizes the amino acid change is in underline and the additional mismatch in lowercase.

\subsubsection{Mycelial Growth}

Mycelial growth was determined by two different approaches:

Measurement of powdery mildew colony area. Zucchini cotyledons were inoculated with four single conidia of each $P$. xanthii isolate using an eyelash and incubated in growth chambers at $17{ }^{\circ} \mathrm{C}$ for 30 days and at $23^{\circ} \mathrm{C}$ for 15 days under a $16 \mathrm{~h}$ photoperiod. After these incubation times, photographs of the cotyledons were taken and the growth area of the colonies was measured using the image analysis software Image 1.52 a (Wayne Rasband, Nacional Institutes of Health, Bethesda, MD, USA). The pixel growth/total pixel ratio of the cotyledon was analysed for each temperature. This experiment was repeated three times for each isolate and condition. The data were analysed by one-way ANOVA following Fisher's LSD test $(\alpha \leq 0.05)$ with a confidence interval (CI) of $95 \%$ using the software GraphPad Prism 8 (GraphPad Software, San Diego, CA, USA).

Quantification of the fungal mass by qPCR. The biomass of the P. xanthii isolates grown over the zucchini samples described above was finely ground under liquid nitrogen. The total DNA was obtained using a MasterPureTM Yeast DNA Purification Kit (Lucigen) and quantified with a Nanodrop (Nanodrop ND-1000, Thermo Scientific). For P. xanthii DNA quantification, the $\beta$-tubulin gene (PfTUB2: KC333362.1) was amplified with the primer pair TubRT6F (5'-CTGCACCTCGCGAAACTAAC-3') and TubRT6R (5'- 
CTACTAAACGCAGCGCAGTC- $3^{\prime}$ ) as previously described [55]. For zucchini DNA quantification, the actin gene (actin-7: XM_008462689.2) was amplified using the primers ActingF (5'-GGCTGGATTTGCCGGTGATGATGC- ${ }^{\prime}$ ) and Acting-R (5'-GGAAGGAGGAAATCAG TGTGAACC-3') as previously described Martínez-Cruz [56]. To generate a standard curve, serial dilutions $\left(10^{-1}\right.$ to $\left.10^{-5}\right)$ of genomic DNA $(0.1-100 \mathrm{ng})$, extracted from noninoculated and inoculated zucchini cotyledons infected with the P. xanthii isolate SF9 were used as templates. After that, quantitative real-time PCR was conducted using a CFX384 Touch Real-Time PCR Detection System (Bio-Rad, Hercules, CA, USA). Amplifications were set up in a $10 \mu \mathrm{L}$ volume containing $0.4 \mu \mathrm{L}$ of each primer (TubRT6F/TubRT6R or ActingF/Acting-R), $3.2 \mu \mathrm{L}$ of water, $5 \mu \mathrm{L}$ of EvaGreen SSoFast ${ }^{\mathrm{TM}}$ Supermix (Bio-Rad, Hercules, $\mathrm{CA}, \mathrm{USA}$ ) and $1 \mu \mathrm{L}$ of genomic DNA (approximately $25 \mathrm{ng}$ ). Real-time PCRs were performed using the following parameters: $98^{\circ} \mathrm{C}$ for $2 \mathrm{~min}, 40$ cycles at $98^{\circ} \mathrm{C}$ for $30 \mathrm{~s}$ and $60{ }^{\circ} \mathrm{C}$ for $30 \mathrm{~s}$. For the melting curve analysis, the temperature was increased by $0.5^{\circ} \mathrm{C}$ for $5 \mathrm{~s}$, from $65^{\circ} \mathrm{C}$ to $95^{\circ} \mathrm{C}$. The threshold cycle $(\mathrm{Ct})$ values were calculated with Bio-Rad CFX Manager software V1.1 to identify significant fluorescence signals rising above background during the early cycles of the exponential growth phase of the PCR amplification process. A standard curve was drawn by plotting the natural log of the threshold cycle $(\mathrm{Ct})$ against the concentrations of the dilution series for genomic DNA. The PfTUB2 and actin-7 gene copy numbers were calculated using the equation proposed by Whelan [57] and expressed as ng of total DNA. Data were analysed by one-way ANOVA following Fisher's LSD test $(\alpha \leq 0.05)$, with a confidence interval (CI) of $95 \%$. For each sample, three replicates were analysed.

\subsection{LAMP Technique}

\subsubsection{LAMP Primer Design}

To distinguish between P. xanthii SDHI-sensitive and SDHI-resistant isolates, a LAMP assay was developed. Four different sets of primers were generated to amplify the SdhC subunit carrying the amino acid change A86V (Set1 and 2; Table 2) and the mutation coding for the substitution G151R (Set3 and 4; Table 2). PrimerExplorer V5 software (https://primerexplorer.jp/e/, accessed on 13 August 2021) was used to develop the LAMP primers B3, F3, FIP and BIP. The FIP primers were composed of the complementary sequence of F1 (F1c) and F2, when the BIP primers included B1 (B1c) and B2 sequences. The last position of the $3^{\prime}$ ends of the B2 and F2 primers was designed to match the mutated nucleotide and, in addition, an extra mismatch was also added at the penultimate position to increase the specificity (Table 2).

\subsubsection{Mixture and Optimization of LAMP Reaction}

To select the optimal set of primers for each amino acid substitution, a first screening was performed using DNA from the SDHI-sensitive isolate SF9 and the two resistant isolates with the A86V change (P. xanthii isolate 19020304D) and the G151R amino acid replacement (isolate 18020307I). The initial LAMP reaction was performed in a $10 \mu \mathrm{L}$ volume containing $6 \mu \mathrm{L}$ of GspSSD Isothermal Mastermix (ISO-001) (OpticGene, Horsham, $\mathrm{UK}), 1 \mu \mathrm{L}$ of the primer mix (1.6 $\mu \mathrm{M}$ each of FIP and BIP, $0.2 \mu \mathrm{M}$ each of F3 and B3), $1 \mu \mathrm{L}$ of genomic DNA (approximately $100 \mathrm{ng}$ ) and $2 \mu \mathrm{L}$ of sterile distilled water. During the first time, the amplification conditions were those recommended by the manufacturer: at $65^{\circ} \mathrm{C}$ for $30 \mathrm{~min}$ with a melting curve analysis step (annealing curve $98-80^{\circ} \mathrm{C}$ ramping at $0.05^{\circ} \mathrm{C}$ per second). All the reactions were performed in Genie II (OpticGene), and the results were directly visualized in the same amplification platform through two values: the time to generate the amplified products, which is the time (min:seconds) of fluorescence emission when the LAMP product passes through the detection threshold, and the melting temperature of the primers, which is an indicator of sample contamination. After the results were analysed, Set1 (for the detection of the A86V change) and Set4 (for the G151R substitution) were selected for further analysis. Then, and for the optimization of the LAMP conditions, a gradient of temperatures $\left(60.5-69.5^{\circ} \mathrm{C}\right)$ was tested. When the optimal temperature was 
selected for each set, and to decrease the amplification time, the concentrations of the FIP and BIP primers were increased to $2 \mu \mathrm{M}$ and remained the same $(0.2 \mu \mathrm{M})$ for F3 and B3. After all these tests, the optimal conditions used for further LAMP assays were for Set1 (A86V), $63.8^{\circ} \mathrm{C}$ for $16 \mathrm{~min}$, and for Set4 (G151R), $62.7 \mathrm{C}$ for $24 \mathrm{~min}$. All the assays were performed three times.

\subsubsection{Specificity of LAMP}

To test the specificity of the LAMP assay, genomic DNA from five different fungal species was used: B. cinerea, D. bryoniae, Erysiphe diffusa, Macrophomina phaseolina and $P$. aphanis. In addition, tubes with genomic DNA from the $P$. xanthii SDHIs-sensitive isolate SF9, the resistant 19020304D (SdhC-A86V) and 18020307I (SdhC-G151R), and sterile distilled water instead of DNA, were also included. The assay was carried out three times under the previously described LAMP conditions.

\subsubsection{Repeatability of LAMP}

The repeatability of Set1 was tested in 8 P. xanthii isolates (18020303T, 19020304D, 18020305L, 18030306D, 18030306M, 18020307K, 18020307L and 18020307R) previously characterized as carrying the amino acid change A86V. Regarding Set4, this test was conducted with only two P. xanthii isolates (18030306K and 18020307I) obtained during SDHI field resistance monitoring studies, which carried the amino acid change G151R. In addition, four SDHI-sensitive isolates (MR03, SF9, SF60 and 311271) were also included. Tubes containing sterile distilled water instead of DNA, were used as negative controls. The reactions were performed under optimal conditions in triplicate.

\subsubsection{Optimization of LAMP Assay Using Spores as Template}

To simplify the process of DNA extraction using conventional methods to obtain approximately $100 \mathrm{ng}$ of total DNA, it is necessary to collect $50 \mathrm{mg}$ of fresh fungal biomass from approximately two zucchini cotyledons infected with powdery mildew [7]. The LAMP assay was performed using DNA obtained from approximately $3 \times 10^{6}$ P. xanthii spores as a template. In this case, DNA extraction was conducted as previously described by Zhu [50]. In brief, $30 \mu \mathrm{L}$ of $10 \times$ Tris-EDTA (TE) buffer was used to collect spores from a mycelium colony by pipetting from two equidistant points of the infected cotyledon. Then, the volume was harvested into a $1.5 \mathrm{~mL}$ tube, boiled in sterile distilled water for $2 \mathrm{~min}$, and incubated for $2 \mathrm{~min}$ on ice, with a final centrifugation at 12,000 rpm for $1 \mathrm{~min}$. The resulting supernatant was used as a template in LAMP reactions following the optimized LAMP conditions, but in this case, and because the DNA quantity and quality were probably low, the reaction time was increased to $30 \mathrm{~min}$. For Set1, DNA extracted from spores [50] and conventional methods (MasterPureTM Yeast DNA Purification Kit, Lucigen) from the SDHI-resistant isolate (19020304D; SdhC-A86V present) was tested. For Set4 the same strategy was employed using DNA from the SdhC-G151R-resistant isolate (18020307I). In addition, tubes including sterile distilled water and DNA extracted (from spores and conventional methods) from the sensitive P. xanthii isolate (SF9) were also tested.

\subsubsection{Testing LAMP Assay in Field Samples}

To test the reliability of the LAMP technique, cucumber-infected leaves with powdery mildew disease collected from a greenhouse in Almeria were studied for LAMP reactions. Ten randomly distributed leaves were collected. P. xanthii colonies were selected from three equidistant points, and their spores were taken by pipetting $30 \mu \mathrm{L}$ of $10 \times$ Tris-EDTA (TE) buffer. The fluid was then deposited in a microcentrifugation tube and processed to extract genomic DNA as previously described and according to Zhu et al. [50]. Later, DNA was LAMP-amplified with Sets 1 and 4. To confirm the LAMP results, in vitro fungicide sensitivity tests to boscalid and fluopyram were also performed. 


\section{Results}

\subsection{Determining the Discriminatory Doses to Boscalid and Fluopyram}

To determine the discriminatory concentrations for the two SDHI fungicides, 26 randomly chosen P. xanthii isolates were tested using a leaf-disc bioassay, and the MIC and $\mathrm{EC}_{50}$ values were determined (Table 1). Based on the sensitivity results, the isolates were divided into three different groups for the two study fungicides. For boscalid, the first group was formed by 10 isolates with an MIC value of $1 \mathrm{mg} / \mathrm{L}$ and a mean $\mathrm{EC}_{50}$ value of $0.38 \mathrm{mg} / \mathrm{L}(0.03-0.97 \mathrm{mg} / \mathrm{L})$, the second had six isolates with an MIC $<10 \mathrm{mg} / \mathrm{L}$ and $\mathrm{EC}_{50}$ value of $1.54 \mathrm{mg} / \mathrm{L}(0.62-3.5 \mathrm{mg} / \mathrm{L})$ and, lastly, a third one with 10 isolates having an $\mathrm{MIC}$ of $10 \mathrm{mg} / \mathrm{L}$ and an $\mathrm{EC}_{50}$ value of $3.60 \mathrm{mg} / \mathrm{L}(0.20-11.17 \mathrm{mg} / \mathrm{L})$. For fluopyram, the first, second and third groups were composed of eight isolates (MIC $=0.1 \mathrm{mg} / \mathrm{L}$ and $\mathrm{EC}_{50}$ value of $\left.0.22 \mathrm{mg} / \mathrm{L}\left(3 \times 10^{-4}-0.77 \mathrm{mg} / \mathrm{L}\right)\right), 13$ isolates $\left(\mathrm{MIC}=1 \mathrm{mg} / \mathrm{L}\right.$ and $\mathrm{EC}_{50}$ value of $\left.0.47 \mathrm{mg} / \mathrm{L}\left(1 \times 10^{-4}-0.87 \mathrm{mg} / \mathrm{L}\right)\right)$, and five isolates $\left(\mathrm{MIC}<10 \mathrm{mg} / \mathrm{L}\right.$ and $\mathrm{EC}_{50}$ value of $2.20 \mathrm{mg} / \mathrm{L}(1.01-4.42 \mathrm{mg} / \mathrm{L}))$, respectively. Therefore, and according to the data, $10 \mathrm{mg} / \mathrm{L}$ was the concentration chosen to perform SDHI field monitoring studies, but in addition to the detection of P. xanthii isolates with different levels of SDHI resistance, concentrations of $25 \mathrm{mg} / \mathrm{L}$ and $50 \mathrm{mg} / \mathrm{L}$, and the recommended field dose of $100 \mathrm{mg} / \mathrm{L}$, were also included for both fungicides [30].

\subsection{SDHI Resistance Field Monitoring Studies}

Two hundred and ninety-eight $P$. xanthii isolates were analysed for sensitivity to boscalid and fluopyram. Samples were taken from the provinces of Almeria (eight locations: D, E, F, and G in 2018 and J, K, L, and M in 2019), Granada (three locations: A, B and C in 2018), Malaga (Q and R in 2019) and Murcia (five locations: H and I in 2018 and N, $\mathrm{O}$ and $\mathrm{P}$ in 2019), representing some of the primary cucurbit production areas in Spain. The four discriminatory concentrations mentioned previously were tested. Based on their ability to grow on discs treated with these discriminatory doses, the P. xanthii isolates were grouped into different categories: (i) sensitive (S), showing no growth at any test concentration, (ii) low resistance (LR), with isolates able to grow at $\leq 25 \mathrm{mg} / \mathrm{L}$ (complete inhibition at 50 and $100 \mathrm{mg} / \mathrm{L}$ ), (iii) moderate resistance (MR), with isolates able to develop until $50 \mathrm{mg} / \mathrm{L}$ (complete inhibition at $100 \mathrm{mg} / \mathrm{L}$ ), (iv) resistant (R), able to grow at all tested concentrations but the mycelium did not completely cover the leaf disc and, finally, (v) high resistance (HR), with isolates able to grow vigorously at all analysed concentrations.

The frequencies by localization, field, year, and phenotype for boscalid and fluopyram are shown in Figure 1 and Tables 3 and 4 . For boscalid (Table 3 ), the $S$ group was formed by 185 isolates (96 in 2018 and 89 in 2019; 62.1\%), and 113 P. xanthii isolates showed different levels of resistance ( $40 \mathrm{LR}, 13.4 \% ; 36 \mathrm{MR}, 12.1 \%$ and $37 \mathrm{R}, 12.4 \%$ ). No boscalid-HR isolate was observed. The provinces of Malaga, which had no resistant isolates in 2019, and Granada, with two R isolates in 2018, showed the lowest percentages of boscalid resistance ( 0 and $0.7 \%$, respectively), while the provinces of Murcia (with an overall $1.7 \% \mathrm{LR}, 6.4 \%$ $\mathrm{MR}$, and $7.4 \% \mathrm{R})$ and Almeria ( $11.7 \% \mathrm{LR}, 5.7 \% \mathrm{MR}$, and $4.4 \% \mathrm{R}$ isolates) had the highest frequencies of resistance (Table 3; Figure 1). For fluopyram (Table 4), 167 isolates (95 in 2018 and 72 in 2019; 56\%) were sensitive, while 131 had some level of resistance: three isolates were LR, $9 \mathrm{MR}, 67 \mathrm{R}$ and $52 \mathrm{HR}$, representing 1, 3, 22.5 and 17.4\%, respectively, of the $P$. xanthii population analysed here. With similar sensitivity results as boscalid, Malaga and Granada had the lower frequencies of resistant isolates (0 and $0.7 \%)$ and Almeria, followed by Murcia, with the highest frequencies ( 24.5 and $18.8 \%$, respectively) (Table 4; Figure 1). In general, boscalid and fluopyram sensitivity remained stable during the two cucurbit seasons, although it should be noted that the levels of boscalid-MR isolates and fluopyram-HR isolates increased from 4.9 to $18.7 \%$ and from 7.7 to $26.5 \%$ in 2018 and 2019, respectively. 

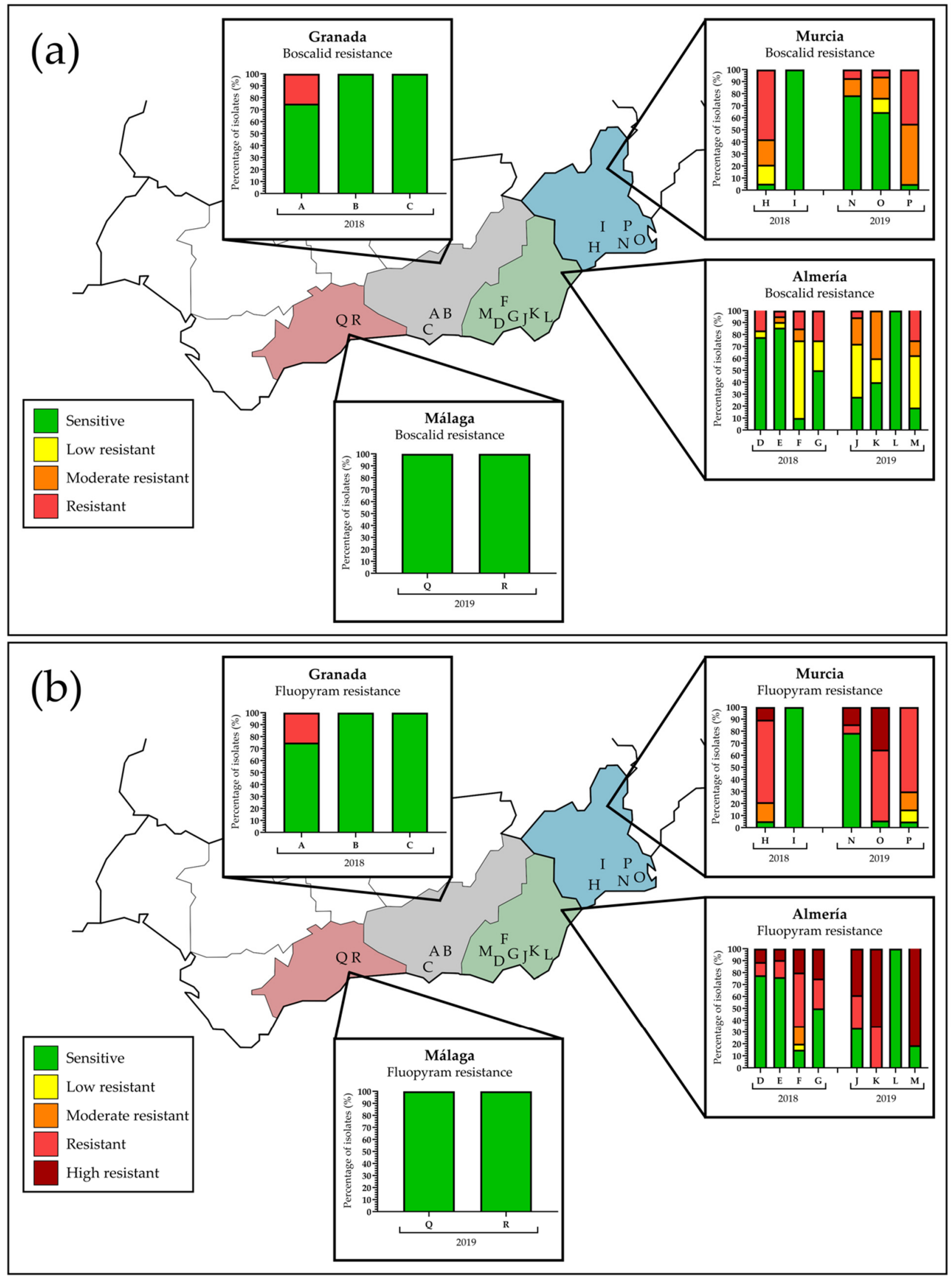

Figure 1. Percentage and phenotype of SDHI isolates detected in the SDHI field monitoring studies: (a) percentage of boscalid-sensitive and boscalid-resistant isolates in provinces of Almeria (eight localizations), Granada (three localizations), Malaga (two localizations) and Murcia (five localizations) during 2018-2019 seasons; (b) percentage of fluopyram-sensitive and fluopyram-resistant isolates in the same provinces and years. 
Table 3. Number and frequencies of boscalid-sensitive and -resistant $P$. xanthii isolates collected from four different cucurbit production areas in Spain during 2018 and 2019 growing seasons.

\begin{tabular}{|c|c|c|c|c|c|c|c|c|c|c|c|c|c|}
\hline \multicolumn{7}{|c|}{$2018(N=143)$} & \multicolumn{7}{|c|}{$2019(N=155)$} \\
\hline \multirow{2}{*}{ Field } & \multirow{2}{*}{ Location } & \multicolumn{5}{|c|}{ Phenotype } & \multirow{2}{*}{ Field } & \multirow{2}{*}{ Location } & \multicolumn{5}{|c|}{ Phenotype } \\
\hline & & $\mathrm{S}$ & LR & MR & $\mathbf{R}$ & HR & & & $S$ & LR & MR & $\mathbf{R}$ & HR \\
\hline $\mathrm{D}$ & \multirow{4}{*}{ Almeria } & $\begin{array}{c}14 \\
(77.8 \%)\end{array}$ & $\begin{array}{c}1 \\
(5.6 \%)\end{array}$ & 0 & $\begin{array}{c}3 \\
(16.7 \%) \\
\end{array}$ & 0 & $\mathrm{~J}$ & \multirow{4}{*}{ Almeria } & $\begin{array}{c}5 \\
(27.8 \%)\end{array}$ & $\begin{array}{c}8 \\
(44.4 \%)\end{array}$ & $\begin{array}{c}4 \\
(22.2 \%)\end{array}$ & $\begin{array}{c}1 \\
(5.6 \%)\end{array}$ & 0 \\
\hline $\mathrm{E}$ & & $\begin{array}{c}18 \\
(85.7 \%)\end{array}$ & $\begin{array}{c}1 \\
(4.8 \%)\end{array}$ & $\begin{array}{c}1 \\
(4.8 \%)\end{array}$ & $\begin{array}{c}1 \\
(4.7 \%)\end{array}$ & 0 & K & & $\begin{array}{c}8 \\
(40.0 \%)\end{array}$ & $\begin{array}{c}4 \\
(20.0 \%)\end{array}$ & $\begin{array}{c}8 \\
(40.0 \%)\end{array}$ & 0 & 0 \\
\hline $\mathrm{F}$ & & $\begin{array}{c}2 \\
(10.0 \%)\end{array}$ & $\begin{array}{c}13 \\
(65.0 \%)\end{array}$ & $\begin{array}{c}2 \\
(10.0 \%)\end{array}$ & $\begin{array}{c}3 \\
(15.0 \%)\end{array}$ & 0 & $\mathrm{~L}$ & & $\begin{array}{c}10 \\
(100 \%)\end{array}$ & 0 & 0 & 0 & 0 \\
\hline G & & $\begin{array}{c}2 \\
(50.0 \%)\end{array}$ & $\begin{array}{c}1 \\
(25.0 \%)\end{array}$ & 0 & $\begin{array}{c}1 \\
(25.0 \%)\end{array}$ & 0 & M & & $\begin{array}{c}3 \\
(18.8 \%)\end{array}$ & $\begin{array}{c}7 \\
(43.8 \%)\end{array}$ & $\begin{array}{c}2 \\
(12.5 \%)\end{array}$ & $\begin{array}{c}4 \\
(25.0 \%)\end{array}$ & 0 \\
\hline $\mathrm{H}$ & \multirow{2}{*}{ Murcia } & $\begin{array}{c}1 \\
(5.3 \%) \\
\end{array}$ & $\begin{array}{c}3 \\
(15.8 \%) \\
\end{array}$ & $\begin{array}{c}4 \\
(21.1 \%) \\
\end{array}$ & $\begin{array}{c}11 \\
(57.9 \%) \\
\end{array}$ & 0 & $\mathrm{~N}$ & \multirow{3}{*}{ Murcia } & $\begin{array}{c}11 \\
(78.6 \%) \\
\end{array}$ & 0 & $\begin{array}{c}2 \\
(14.3 \%) \\
\end{array}$ & $\begin{array}{c}1 \\
(7.1 \%) \\
\end{array}$ & 0 \\
\hline \multirow[t]{2}{*}{ I } & & $\begin{array}{c}13 \\
(100 \%)\end{array}$ & 0 & 0 & 0 & 0 & $\mathrm{O}$ & & $\begin{array}{c}11 \\
(64.7 \%)\end{array}$ & $\begin{array}{c}2 \\
(11.8 \%)\end{array}$ & $\begin{array}{c}3 \\
(17.6 \%)\end{array}$ & $\begin{array}{c}1 \\
(5.9 \%)\end{array}$ & 0 \\
\hline & & & & & & & $\mathrm{P}$ & & $\begin{array}{c}1 \\
(5.0 \%)\end{array}$ & 0 & $\begin{array}{c}10 \\
(50.0 \%)\end{array}$ & $\begin{array}{c}9 \\
(45.0 \%)\end{array}$ & 0 \\
\hline A & \multirow{3}{*}{ Granada } & $\begin{array}{c}6 \\
(75.0 \%)\end{array}$ & 0 & 0 & $\begin{array}{c}2 \\
(25.0 \%)\end{array}$ & 0 & Q & \multirow{2}{*}{ Malaga } & $\begin{array}{c}20 \\
(100 \%)\end{array}$ & 0 & 0 & 0 & 0 \\
\hline B & & $\begin{array}{c}20 \\
(100 \%)\end{array}$ & 0 & 0 & 0 & 0 & $\mathrm{R}$ & & $\begin{array}{c}20 \\
(100 \%)\end{array}$ & 0 & 0 & 0 & 0 \\
\hline \multirow[t]{2}{*}{$\mathrm{C}$} & & $\begin{array}{c}20 \\
(100 \%)\end{array}$ & 0 & 0 & 0 & 0 & & & & & & & \\
\hline & Total & $\begin{array}{c}96 \\
(67.1 \%)\end{array}$ & $\begin{array}{c}19 \\
(13.3 \%)\end{array}$ & $\begin{array}{c}7 \\
(4.9 \%)\end{array}$ & $\begin{array}{c}21 \\
(14.7 \%)\end{array}$ & 0 & & Total & $\begin{array}{c}89 \\
(57.4 \%)\end{array}$ & $\begin{array}{c}21 \\
(13.5 \%)\end{array}$ & $\begin{array}{c}29 \\
(18.7 \%)\end{array}$ & $\begin{array}{c}16 \\
(10.3 \%)\end{array}$ & 0 \\
\hline
\end{tabular}

Phenotypes are indicated as: $\mathrm{S}$, sensitive; LR, low resistance; MR, moderate resistance; $R$, resistant; $H R$, high resistance.

Table 4. Number and frequencies of fluopyram-sensitive and -resistant P. xanthii isolates collected from four different cucurbit production areas in Spain during 2018 and 2019 growing seasons.

\begin{tabular}{|c|c|c|c|c|c|c|c|c|c|c|c|c|c|}
\hline \multirow{3}{*}{ Field } & \multicolumn{6}{|c|}{$2018(N=143)$} & \multicolumn{7}{|c|}{$2019(N=155)$} \\
\hline & \multirow{2}{*}{ Location } & \multicolumn{5}{|c|}{ Phenotype } & \multirow{2}{*}{ Field } & \multirow{2}{*}{ Location } & \multicolumn{5}{|c|}{ Phenotype } \\
\hline & & $S$ & LR & MR & $\mathbf{R}$ & HR & & & $S$ & LR & MR & $\mathbf{R}$ & HR \\
\hline $\mathrm{D}$ & \multirow{4}{*}{ Almeria } & $\begin{array}{c}14 \\
(77.8 \%)\end{array}$ & 0 & 0 & $\begin{array}{c}2 \\
(11.1 \%)\end{array}$ & $\begin{array}{c}2 \\
(11.1 \%)\end{array}$ & $\mathrm{J}$ & \multirow{4}{*}{ Almeria } & $\begin{array}{c}6 \\
(33.3 \%)\end{array}$ & 0 & 0 & $\begin{array}{c}5 \\
(27.8 \%)\end{array}$ & $\begin{array}{c}7 \\
(38.9 \%)\end{array}$ \\
\hline E & & $\begin{array}{c}16 \\
(76.2 \%)\end{array}$ & 0 & 0 & $\begin{array}{c}3 \\
(14.3 \%)\end{array}$ & $\begin{array}{c}2 \\
(9.5 \%)\end{array}$ & K & & 0 & 0 & 0 & $\begin{array}{c}7 \\
(35.0 \%)\end{array}$ & $\begin{array}{c}13 \\
(65.0 \%)\end{array}$ \\
\hline $\mathrm{F}$ & & $3(15 \%)$ & $\begin{array}{c}1 \\
(5.0 \%)\end{array}$ & $\begin{array}{c}3 \\
(15.0 \%)\end{array}$ & $\begin{array}{c}9 \\
(45.0 \%)\end{array}$ & $\begin{array}{c}4 \\
(20.0 \%)\end{array}$ & $\mathrm{L}$ & & $\begin{array}{c}10 \\
(100 \%)\end{array}$ & 0 & 0 & 0 & 0 \\
\hline G & & $2(50 \%)$ & 0 & 0 & $\begin{array}{c}1 \\
(25.0 \%)\end{array}$ & $\begin{array}{c}1 \\
(25.0 \%)\end{array}$ & M & & $\begin{array}{c}3 \\
(18.8 \%)\end{array}$ & 0 & 0 & 0 & $\begin{array}{c}13 \\
(81.3 \%)\end{array}$ \\
\hline $\mathrm{H}$ & \multirow{2}{*}{ Murcia } & $\begin{array}{c}1 \\
(5.3 \%) \\
\end{array}$ & 0 & $\begin{array}{c}3 \\
(15.8 \%)\end{array}$ & $\begin{array}{c}13 \\
(68.4 \%) \\
\end{array}$ & $\begin{array}{c}2 \\
(10.5 \%)\end{array}$ & $\mathrm{N}$ & \multirow{3}{*}{ Murcia } & $\begin{array}{c}11 \\
(78.6 \%)\end{array}$ & 0 & 0 & $\begin{array}{c}1 \\
(7.1 \%) \\
\end{array}$ & $\begin{array}{c}2 \\
(14.3 \%)\end{array}$ \\
\hline \multirow[t]{2}{*}{ I } & & $\begin{array}{c}13 \\
(100 \%)\end{array}$ & 0 & 0 & 0 & 0 & $\mathrm{O}$ & & $\begin{array}{c}1 \\
(5.9 \%)\end{array}$ & 0 & 0 & $\begin{array}{c}10 \\
(58.8 \%)\end{array}$ & $\begin{array}{c}6 \\
(35.3 \%)\end{array}$ \\
\hline & & & & & & & $\mathrm{P}$ & & $\begin{array}{c}1 \\
(5.0 \%)\end{array}$ & $\begin{array}{c}2 \\
(10 \%)\end{array}$ & $\begin{array}{c}3 \\
(15.0 \%)\end{array}$ & $\begin{array}{c}14 \\
(70.0 \%)\end{array}$ & 0 \\
\hline A & \multirow{3}{*}{ Granada } & $\begin{array}{c}6 \\
(75 \%)\end{array}$ & 0 & 0 & $\begin{array}{c}2 \\
(25.0 \%)\end{array}$ & 0 & Q & \multirow{2}{*}{ Malaga } & $\begin{array}{c}20 \\
(100 \%)\end{array}$ & 0 & 0 & 0 & 0 \\
\hline B & & $\begin{array}{c}20 \\
(100 \%)\end{array}$ & 0 & 0 & 0 & 0 & $\mathrm{R}$ & & $\begin{array}{c}20 \\
(100 \%)\end{array}$ & 0 & 0 & 0 & 0 \\
\hline \multirow[t]{2}{*}{ C } & & $\begin{array}{c}20 \\
(100 \%)\end{array}$ & 0 & 0 & 0 & 0 & & & & & & & \\
\hline & Total & $\begin{array}{c}95 \\
(66.4 \%)\end{array}$ & $\begin{array}{c}1 \\
(0.7 \%)\end{array}$ & $\begin{array}{c}6 \\
(4.2 \%)\end{array}$ & $\begin{array}{c}30 \\
(21.0 \%)\end{array}$ & $\begin{array}{c}11 \\
(7.7 \%)\end{array}$ & & Total & $\begin{array}{c}72 \\
(46.5 \%)\end{array}$ & $\begin{array}{c}2 \\
(1.3 \%)\end{array}$ & $\begin{array}{c}3 \\
(1.9 \%)\end{array}$ & $\begin{array}{c}37 \\
(23.9 \%)\end{array}$ & $\begin{array}{c}41 \\
(26.5 \%)\end{array}$ \\
\hline
\end{tabular}

Phenotypes are indicated as: S, sensitive; LR, low resistance; MR, moderate resistance; R, resistant; HR, highly resistant. 


\subsection{Fungicide Sensitivity Plant Assay}

An inoculation of selected P. xanthii isolates was conducted on fungicide-sprayed and nonsprayed melon leaves to validate the results obtained during the in vitro fungicide sensitivity assays for boscalid and fluopyram. As expected, typical powdery mildew symptoms were observed on the leaves sprayed with distilled sterile water 15 days after P. xanthii inoculation. Regarding the fungicide-treated plants, the field rates of Cantus (boscalid) and Luna Privilege (fluopyram)-controlled S isolates (SF9, 81210 and 18130304A) but not the P. xanthii isolates that showed some level of resistance (LR, MR, R or HR) to the SDHI fungicides in in vitro tests, with no difference in the development of the different resistant phenotypes (data not shown).

\subsection{Analysis of SdhB, SdhC and SdhD Genes in P. xanthii Isolates}

Gene fragments containing the ORFs of the three SDH subunits were found in the P. xanthii genome. For the ShdB subunit, the ORF had a length of $886 \mathrm{bp}$, which included two exons (345 bp and $471 \mathrm{bp}$ ) and one intron (70 bp), having a shared identity of $99.91 \%$ (e-value of 0) compared to the P. xanthii ShdB gene (LC522530.1) [58] and 92.65\% (e-value of $2^{-171}$ ) compared to the ShdB protein of Blumeria graminis f. sp. hordei (CCU74871.1). For the ShdC subunit, the ORF was $737 \mathrm{bp}$ in length, with three exons (43, 87 and $446 \mathrm{bp})$, two introns (66 bp and $95 \mathrm{bp}$ ) and shared identities of $100 \%$ (e-value of 0 ) and $76.15 \%$ (e-value of $5^{-66}$ ) with the SdhC gene of P. xanthii (LC522548.1) and the ShdC protein of $B$. graminis f. sp. hordei (CCU79401.1), respectively. Lastly, for the SdhD subunit, an ORF of $695 \mathrm{bp}$, which had two exons (223 bp and $353 \mathrm{bp}$ ) and one intron measuring $119 \mathrm{bp}$, was obtained. The nucleotide sequence mapped with the P. xanthii SdhD sequence (LC522550.1) had $99.98 \%$ shared identity (e-value of 0 ) and $76.15 \%$ shared identity (e-value of $5^{-66}$ ) with the SdhD protein of B. graminis f.sp. hordei (CCU79401.1). Using this information, the complete ORFs of the genes SdhB, SdhC and SdhD were PCR-amplified from 75 $P$. xanthii isolates (nine sensitive and 66 with different levels of resistance to boscalid and fluopyram) using the corresponding primer pairs listed in Table 2. Once the sequences obtained for the different subunits and isolates were analysed, no differences were found in the SdhB and SdhD subunits; however, two-point mutations were detected in SdhC. In this subunit, fifty-three isolates that showed different levels of resistance (LR, MR, $R$ or HR) to boscalid and fluopyram and $11 P$. xanthii isolates that were $\mathrm{S}$ to boscalid and $\mathrm{R}$ or HR to fluopyram presented an amino acid change of alanine to valine at position 86 (A86V; Table 5). However, the substitution of glycine for arginine at position 151 (G151R) was present in two isolates collected from Almeria and Murcia that were R to boscalid but S or LR to fluopyram (Table 5). The accession numbers of the SdhC sequences for four representative P. xanthii isolates carrying A86V and G151R amino acid changes were submitted to the DDBJ/EMBL/GenBank database (accession numbers MZ285078-MZ285081).

\subsection{Fitness Cost of SDHI Resistance}

To determine if the SDHI-resistant isolates had fitness penalties, two biological parameters, conidial germination and mycelium growth, were investigated at two temperatures $\left(17\right.$ and $23^{\circ} \mathrm{C}$ ) and different times for the nine P. xanthii isolates (three $\mathrm{S}$ and six representing different levels of SDHI resistance). 
Table 5. Fluopyram and boscalid MIC values, phenotype, and amino acid substitution in the SdhC subunit in P. xanthii isolates collected during the 2018 and 2019 cucurbit growing seasons in Spain.

\begin{tabular}{|c|c|c|c|c|c|c|c|}
\hline \multirow{2}{*}{ Isolate } & \multirow{2}{*}{ Location } & \multirow{2}{*}{ Host } & \multicolumn{2}{|c|}{ MIC Value (mg/L) } & \multicolumn{2}{|c|}{ Phenotype } & \multirow{2}{*}{$\begin{array}{l}\text { Amino Acid } \\
\text { Substitution }\end{array}$} \\
\hline & & & Boscalid & Fluopyram & Boscalid & Fluopyram & \\
\hline 18130301D & Granada & Cucumber & $>100^{1}$ & $>100^{1}$ & $\mathrm{R}$ & $\mathrm{R}$ & $\mathrm{A} 86 \mathrm{~V}$ \\
\hline $18130301 \mathrm{E}$ & Granada & Cucumber & $>100^{1}$ & $>100^{1}$ & $\mathrm{R}$ & $\mathrm{R}$ & $\mathrm{A} 86 \mathrm{~V}$ \\
\hline $18020303 \mathrm{M}$ & Almeria & Cucumber & $>100^{1}$ & $>100^{2}$ & $\mathrm{R}$ & $\mathrm{HR}$ & $\mathrm{A} 86 \mathrm{~V}$ \\
\hline 18020303Q & Almeria & Cucumber & $>100^{1}$ & $>100^{1}$ & $\mathrm{R}$ & $\mathrm{R}$ & $\mathrm{A} 86 \mathrm{~V}$ \\
\hline $18020303 S$ & Almeria & Cucumber & $<50$ & $>100^{2}$ & LR & $\mathrm{HR}$ & $\mathrm{A} 86 \mathrm{~V}$ \\
\hline $18020303 \mathrm{~T}$ & Almeria & Cucumber & $>100^{1}$ & $>100^{1}$ & $\mathrm{R}$ & $\mathrm{R}$ & $\mathrm{A} 86 \mathrm{~V}$ \\
\hline $18020305 \mathrm{~A}$ & Almeria & Cucumber & 0 & $>100^{1}$ & $S$ & $\mathrm{R}$ & $\mathrm{A} 86 \mathrm{~V}$ \\
\hline $18020305 \mathrm{~K}$ & Almeria & Cucumber & $<50$ & $>100^{2}$ & LR & $\mathrm{HR}$ & $\mathrm{A} 86 \mathrm{~V}$ \\
\hline $18020305 \mathrm{~L}$ & Almeria & Cucumber & $<100$ & $>100^{1}$ & MR & $\mathrm{R}$ & $\mathrm{A} 86 \mathrm{~V}$ \\
\hline $18020305 \mathrm{P}$ & Almeria & Cucumber & 0 & $>100^{2}$ & $\mathrm{~S}$ & HR & $\mathrm{A} 86 \mathrm{~V}$ \\
\hline $18020305 S$ & Almeria & Cucumber & $>100^{1}$ & $>100^{1}$ & $\mathrm{R}$ & $\mathrm{R}$ & $\mathrm{A} 86 \mathrm{~V}$ \\
\hline 18030306A & Murcia & Cucumber & $<100$ & $>100^{1}$ & MR & $\mathrm{R}$ & $\mathrm{A} 86 \mathrm{~V}$ \\
\hline 18030306B & Murcia & Cucumber & $>100^{1}$ & $>100^{2}$ & $\mathrm{R}$ & HR & $\mathrm{A} 86 \mathrm{~V}$ \\
\hline $18030306 \mathrm{C}$ & Murcia & Cucumber & $>100^{1}$ & $>100^{1}$ & $\mathrm{R}$ & $\mathrm{R}$ & A86V \\
\hline $18030306 \mathrm{D}$ & Murcia & Cucumber & $<100$ & $<100$ & MR & MR & $\mathrm{A} 86 \mathrm{~V}$ \\
\hline $18030306 \mathrm{E}$ & Murcia & Cucumber & 0 & $>100^{1}$ & $\mathrm{~S}$ & $\mathrm{R}$ & $\mathrm{A} 86 \mathrm{~V}$ \\
\hline $18030306 \mathrm{~F}$ & Murcia & Cucumber & $>100^{1}$ & $>100^{1}$ & $\mathrm{R}$ & $\mathrm{R}$ & A86V \\
\hline $18030306 \mathrm{G}$ & Murcia & Cucumber & $>100^{1}$ & $>100^{1}$ & $\mathrm{R}$ & $\mathrm{R}$ & $\mathrm{A} 86 \mathrm{~V}$ \\
\hline $18030306 \mathrm{H}$ & Murcia & Cucumber & $>100^{1}$ & $>100^{1}$ & $\mathrm{R}$ & $\mathrm{R}$ & A86V \\
\hline $18030306 \mathrm{I}$ & Murcia & Cucumber & $<100$ & $<100$ & MR & MR & $\mathrm{A} 86 \mathrm{~V}$ \\
\hline $18030306 \mathrm{~J}$ & Murcia & Cucumber & $>100^{1}$ & $>100^{1}$ & $\mathrm{R}$ & $\mathrm{R}$ & A86V \\
\hline $18030306 \mathrm{~K}$ & Murcia & Cucumber & $>100^{1}$ & $<50$ & $\mathrm{R}$ & LR & G151R \\
\hline 18030306L & Murcia & Cucumber & $<50$ & $>100^{1}$ & LR & $\mathrm{R}$ & $\mathrm{A} 86 \mathrm{~V}$ \\
\hline $18030306 \mathrm{M}$ & Murcia & Cucumber & $<100$ & $>100^{1}$ & MR & $\mathrm{R}$ & $\mathrm{A} 86 \mathrm{~V}$ \\
\hline $18030306 \mathrm{~N}$ & Murcia & Cucumber & $<50$ & $>100^{2}$ & LR & $\mathrm{HR}$ & $\mathrm{A} 86 \mathrm{~V}$ \\
\hline $18030306 \mathrm{O}$ & Murcia & Cucumber & $>100^{1}$ & $>100^{1}$ & $\mathrm{R}$ & $\mathrm{R}$ & $\mathrm{A} 86 \mathrm{~V}$ \\
\hline $18030306 \mathrm{P}$ & Murcia & Cucumber & $>100^{1}$ & $>100^{1}$ & $\mathrm{R}$ & $\mathrm{R}$ & $\mathrm{A} 86 \mathrm{~V}$ \\
\hline 18030306Q & Murcia & Cucumber & $>100^{1}$ & $<100$ & $\mathrm{R}$ & MR & $\mathrm{A} 86 \mathrm{~V}$ \\
\hline $18030306 \mathrm{~S}$ & Murcia & Cucumber & $<50$ & $>100^{1}$ & LR & $\mathrm{R}$ & $\mathrm{A} 86 \mathrm{~V}$ \\
\hline $18030306 \mathrm{U}$ & Murcia & Cucumber & $>100^{1}$ & $>100^{1}$ & $\mathrm{R}$ & $\mathrm{R}$ & $\mathrm{A} 86 \mathrm{~V}$ \\
\hline 18020307A & Almeria & Cucumber & $>100^{1}$ & $>100^{1}$ & $\mathrm{R}$ & $\mathrm{R}$ & $\mathrm{A} 86 \mathrm{~V}$ \\
\hline 18020307B & Almeria & Cucumber & $>100^{1}$ & $<100$ & $\mathrm{R}$ & MR & A86V \\
\hline 18020307C & Almeria & Cucumber & $<50$ & $<100$ & LR & MR & A86V \\
\hline 18020307D & Almeria & Cucumber & $<50$ & $<50$ & LR & LR & $\mathrm{A} 86 \mathrm{~V}$ \\
\hline 18020307E & Almeria & Cucumber & $<50$ & $>100^{2}$ & LR & HR & $\mathrm{A} 86 \mathrm{~V}$ \\
\hline $18020307 \mathrm{~F}$ & Almeria & Cucumber & $<50$ & $>100^{1}$ & LR & $\mathrm{R}$ & $\mathrm{A} 86 \mathrm{~V}$ \\
\hline $18020307 \mathrm{H}$ & Almeria & Cucumber & $<100$ & $>100^{1}$ & MR & $\mathrm{R}$ & $\mathrm{A} 86 \mathrm{~V}$ \\
\hline $18020307 \mathrm{I}$ & Almeria & Cucumber & $>100^{1}$ & 0 & $\mathrm{R}$ & S & G151R \\
\hline $18020307 \mathrm{~J}$ & Almeria & Cucumber & $<50$ & $>100^{2}$ & LR & $\mathrm{HR}$ & $\mathrm{A} 86 \mathrm{~V}$ \\
\hline 18020307K & Almeria & Cucumber & $<50$ & $>100^{2}$ & LR & $\mathrm{HR}$ & A86V \\
\hline $18020307 \mathrm{~L}$ & Almeria & Cucumber & $<50$ & $>100^{1}$ & LR & $\mathrm{R}$ & $\mathrm{A} 86 \mathrm{~V}$ \\
\hline $18020307 \mathrm{M}$ & Almeria & Cucumber & $<50$ & $>100^{2}$ & LR & HR & A86V \\
\hline $18020307 \mathrm{~N}$ & Almeria & Cucumber & $<50$ & $<100$ & LR & MR & $\mathrm{A} 86 \mathrm{~V}$ \\
\hline 18020307P & Almeria & Cucumber & $<50$ & $>100^{1}$ & LR & $\mathrm{R}$ & $\mathrm{A} 86 \mathrm{~V}$ \\
\hline 18020307Q & Almeria & Cucumber & $<50$ & $>100^{1}$ & LR & $\mathrm{R}$ & $\mathrm{A} 86 \mathrm{~V}$ \\
\hline 18020307R & Almeria & Cucumber & $<50$ & $>100^{1}$ & LR & $\mathrm{R}$ & $\mathrm{A} 86 \mathrm{~V}$ \\
\hline $18020307 \mathrm{~S}$ & Almeria & Cucumber & $<100$ & $>100^{1}$ & MR & $\mathrm{R}$ & $\mathrm{A} 86 \mathrm{~V}$ \\
\hline $18020307 \mathrm{~T}$ & Almeria & Cucumber & $<50$ & $>100^{1}$ & LR & $\mathrm{R}$ & $\mathrm{A} 86 \mathrm{~V}$ \\
\hline 18020208B & Murcia & Zucchini & $<50$ & $>100^{2}$ & LR & HR & $\mathrm{A} 86 \mathrm{~V}$ \\
\hline $18020208 \mathrm{D}$ & Murcia & Zucchini & $>100^{1}$ & $>100^{1}$ & $\mathrm{R}$ & $\mathrm{R}$ & $\mathrm{A} 86 \mathrm{~V}$ \\
\hline $19020203 \mathrm{~A}$ & Almeria & Zucchini & $<100$ & $>100^{2}$ & MR & HR & $\mathrm{A} 86 \mathrm{~V}$ \\
\hline 19020203B & Almeria & Zucchini & $<50$ & $>100^{1}$ & LR & $\mathrm{R}$ & $\mathrm{A} 86 \mathrm{~V}$ \\
\hline $19020203 C$ & Almeria & Zucchini & $<50$ & $>100^{1}$ & LR & $\mathrm{R}$ & $\mathrm{A} 86 \mathrm{~V}$ \\
\hline
\end{tabular}


Table 5. Cont.

\begin{tabular}{|c|c|c|c|c|c|c|c|}
\hline \multirow{2}{*}{ Isolate } & \multirow{2}{*}{ Location } & \multirow{2}{*}{ Host } & \multicolumn{2}{|c|}{ MIC Value (mg/L) } & \multicolumn{2}{|c|}{ Phenotype } & \multirow{2}{*}{$\begin{array}{l}\text { Amino Acid } \\
\text { Substitution }\end{array}$} \\
\hline & & & Boscalid & Fluopyram & Boscalid & Fluopyram & \\
\hline $19020203 \mathrm{~F}$ & Almeria & Zucchini & $>100^{1}$ & $>100^{2}$ & $\mathrm{R}$ & HR & $\mathrm{A} 86 \mathrm{~V}$ \\
\hline $19020203 \mathrm{H}$ & Almeria & Zucchini & $<100$ & $>100^{1}$ & MR & $\mathrm{R}$ & $\mathrm{A} 86 \mathrm{~V}$ \\
\hline $19020203 I$ & Almeria & Zucchini & $<50$ & $>100^{2}$ & LR & HR & $\mathrm{A} 86 \mathrm{~V}$ \\
\hline 19020203J & Almeria & Zucchini & $<50$ & $>100^{1}$ & LR & $\mathrm{R}$ & $\mathrm{A} 86 \mathrm{~V}$ \\
\hline $19020304 \mathrm{~A}$ & Almeria & Cucumber & $<50$ & $>100^{1}$ & LR & $\mathrm{R}$ & $\mathrm{A} 86 \mathrm{~V}$ \\
\hline 19020304B & Almeria & Cucumber & 0 & $>100^{2}$ & $S$ & HR & $\mathrm{A} 86 \mathrm{~V}$ \\
\hline $19020304 \mathrm{C}$ & Almeria & Cucumber & 0 & $>100^{2}$ & $S$ & HR & $\mathrm{A} 86 \mathrm{~V}$ \\
\hline 19020304D & Almeria & Cucumber & 0 & $>100^{2}$ & S & HR & $\mathrm{A} 86 \mathrm{~V}$ \\
\hline $19020304 \mathrm{G}$ & Almeria & Cucumber & 0 & $>100^{1}$ & $S$ & $\mathrm{R}$ & $\mathrm{A} 86 \mathrm{~V}$ \\
\hline $19020304 \mathrm{I}$ & Almeria & Cucumber & 0 & $>100^{1}$ & $S$ & $\mathrm{R}$ & $\mathrm{A} 86 \mathrm{~V}$ \\
\hline $19020304 \mathrm{~J}$ & Almeria & Cucumber & 0 & $>100^{1}$ & $S$ & $\mathrm{R}$ & $\mathrm{A} 86 \mathrm{~V}$ \\
\hline $19020304 \mathrm{O}$ & Almeria & Cucumber & 0 & $>100^{1}$ & S & $\mathrm{R}$ & $\mathrm{A} 86 \mathrm{~V}$ \\
\hline $19020304 S$ & Almeria & Cucumber & 0 & $>100^{1}$ & S & $\mathrm{R}$ & $\mathrm{A} 86 \mathrm{~V}$ \\
\hline
\end{tabular}

${ }^{1}$ Normal growth of the mycelium. ${ }^{2}$ Vigorous growth of the mycelium. Phenotypes are indicated as: S, sensitive; LR, low resistance; MR, moderate resistance; $R$, resistant; HR, high resistance.

For conidial germination, the number of ungerminated spores, germinated spores with a single germ tube, and spores with two or more germ tubes were observed for each isolate (Figure 2). In general, there were no differences between the SDHI-resistant isolates and the sensitive isolates, and the few significant differences did not follow any phenotypic pattern. For the ungerminated conidia, the number was higher at $24 \mathrm{~h}$, and it was reduced at $48 \mathrm{~h}$ and $72 \mathrm{~h}$, especially at $23^{\circ} \mathrm{C}$. The number of conidia with a germ tube remained below $20 \%$ three times, increasing slightly at 48 and $72 \mathrm{~h}$ at $23^{\circ} \mathrm{C}$. During this stage, and at $17^{\circ} \mathrm{C}$, three of the SDHI-resistant isolates (18020305L, 18020303Q and 18020307J) had significantly higher values, at approximately $10 \%$ cotyledon coverage, than the sensitive isolates ( $1 \%$ or less) at $72 \mathrm{~h}$. Lastly, the percentage of conidia with two or more germ tubes, which are those that will normally develop haustoria and complete infection, increased notably at 48 and $72 \mathrm{~h}$ at both temperatures. At $17^{\circ} \mathrm{C}$, all the SDHI-resistant isolates had a percentage of spores with two or more germ tubes that was significantly lower than that of the sensitive isolates ( $78-72 \%$ for the sensitives versus $59-48 \%$ for the resistant ones), which was in contrast with the results of the spores with one germ tube at the same temperature after $72 \mathrm{~h}$ (Figure 2).

The same trend accounted for mycelial growth, which was estimated by two different techniques, image analysis and qPCR. Using image analysis, the data shown in Figure 3 represent the mycelial growth rate in terms of leaf surface covered by powdery mildew and expressed as percentage of fungal colony growth. The comparison between SDHI-sensitive and SDHI-resistant $P$. xanthii isolates showed no significant differences between the two groups $(\alpha \leq 0.05)$ (Figure 3). At $17^{\circ} \mathrm{C}$, the sensitive isolates showed a mean fungal colony growth of $8.4 \%$ (isolate 81210 ) and $5.5 \%$ for $18130304 \mathrm{~A}$, while the SDHI-resistant isolates had values of $5.8,6.3,7.0$ and $5.8 \%$ for $18020307 \mathrm{D}\left(\mathrm{B}^{\mathrm{LR}} \mathrm{F}^{\mathrm{LR}}\right), 18020305 \mathrm{~L}\left(\mathrm{~B}^{\mathrm{MR}} \mathrm{F}^{\mathrm{R}}\right), 18020303 \mathrm{Q}$ $\left(B^{R} F^{R}\right)$, and $18020307 \mathrm{~J}\left(B^{L R} F^{H R}\right)$, respectively. The growth at $23^{\circ} \mathrm{C}$ also remained similar between SDHI-sensitive and SDHI-resistant isolates. The mean values for 81210 and $18130304 \mathrm{~A}$ were 4.4 and $3.7 \%$, respectively, and the resistant isolates had similar results: $3.1 \%$ for $18020307 \mathrm{D}\left(\mathrm{B}^{\mathrm{LR}} \mathrm{F}^{\mathrm{LR}}\right), 3.5 \%$ for $18020305 \mathrm{~L}\left(\mathrm{~B}^{\mathrm{MR}} \mathrm{F}^{\mathrm{R}}\right), 3.7 \%$ for $18020303 \mathrm{Q}\left(\mathrm{B}^{\mathrm{R}} \mathrm{F}^{\mathrm{R}}\right)$ and $2.3 \%$ for $18020307 \mathrm{~J}\left(\mathrm{~B}^{\mathrm{LR}} \mathrm{F}^{\mathrm{HR}}\right)$. Regarding temperatures, the colonies covered more cotyledon surface at $17^{\circ} \mathrm{C}$ than at $23^{\circ} \mathrm{C}$, which was explained by the different time of incubation of 30 days instead of 15 days. In addition, the quantification of the PfTUB2 gene copy number showed no significant differences $(\alpha \leq 0.05)$ in the growth of SDHI-sensitive and SDHIresistant (LR, MR, R and HR) isolates for the two temperatures tested here. Furthermore, no difference was observed in the amount of DNA in the same isolate between 17 and $23^{\circ} \mathrm{C}$. No pattern related to phenotype or temperature was observed, indicating that the amount of DNA in the colony does not depend on these two factors. For example, the DNA copy 
numbers obtained for the sensitive isolates 81210 and $18130304 \mathrm{~A}$ and the resistant isolate $18020307 \mathrm{~J}\left(\mathrm{~B}^{\mathrm{LR}} \mathrm{F}^{\mathrm{HR}}\right)$ at $17^{\circ} \mathrm{C}$ and $23^{\circ} \mathrm{C}$ were below $1 \times 10^{10}$, while $18020307 \mathrm{D}\left(\mathrm{B}^{\mathrm{LR}} \mathrm{F}^{\mathrm{LR}}\right)$ and $18020305 \mathrm{~L}\left(\mathrm{~B}^{\mathrm{MR}} \mathrm{F}^{\mathrm{R}}\right)$ had values above $2 \times 10^{10}$ at both temperatures, even reaching $4 \times 10^{10}$ DNA copies for $18020307 \mathrm{D}$ at $23{ }^{\circ} \mathrm{C}$. The results obtained by image analysis and qPCR quantification were uniform.

$17^{\circ} \mathrm{C}$
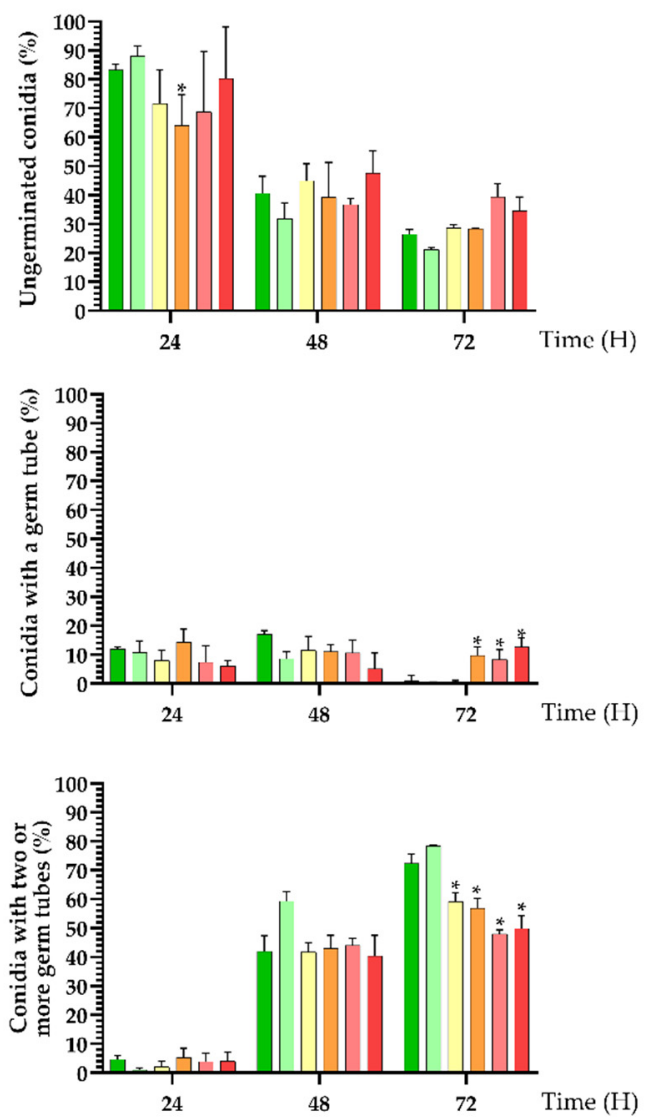

$23{ }^{\circ} \mathrm{C}$
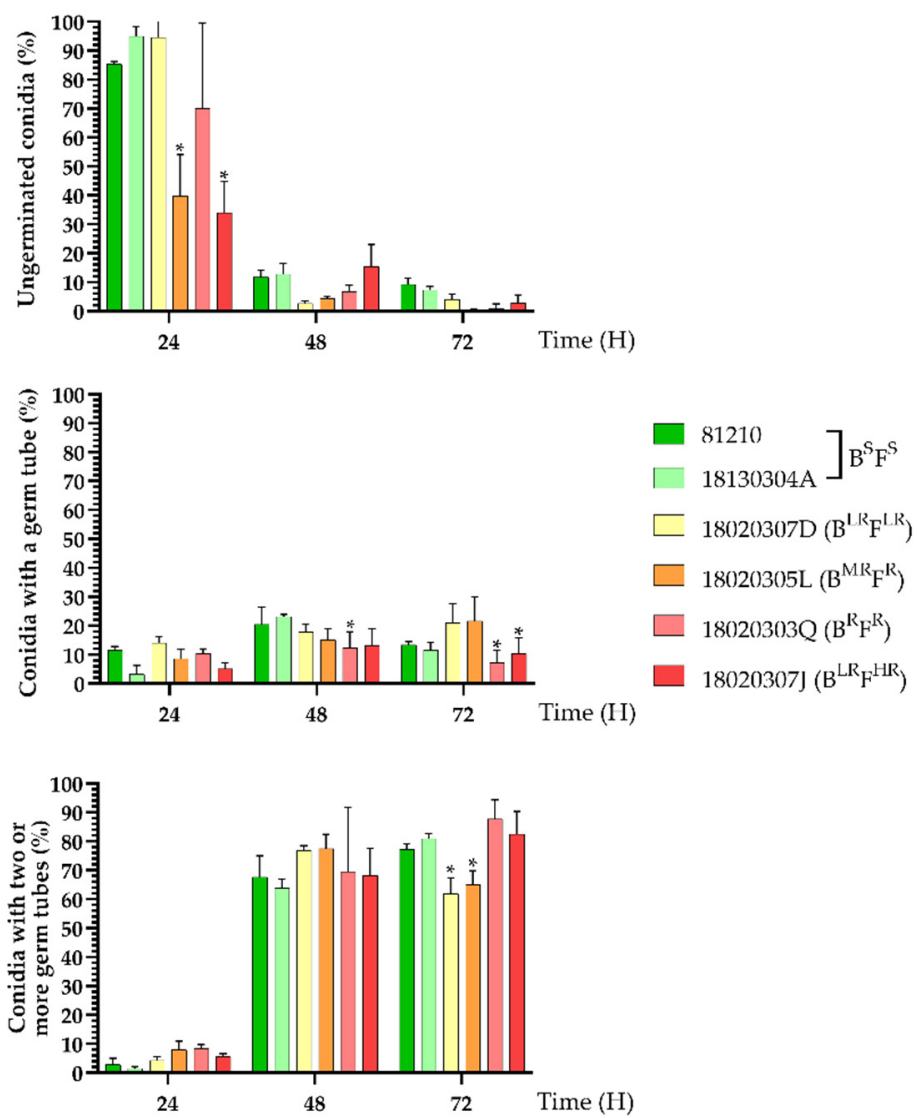

Figure 2. Percentage of ungerminated conidia, conidia with germ tube and conidia with two or more germ tubes incubated at $17{ }^{\circ} \mathrm{C}$ and $23{ }^{\circ} \mathrm{C}$ for 24,48 and 72 h. P. xanthii isolates with different SDHI phenotypes (sensitive and low resistance, moderate resistance, resistant and high resistance to boscalid or fluopyram) were tested. For significantly different values, * is showed on the column.

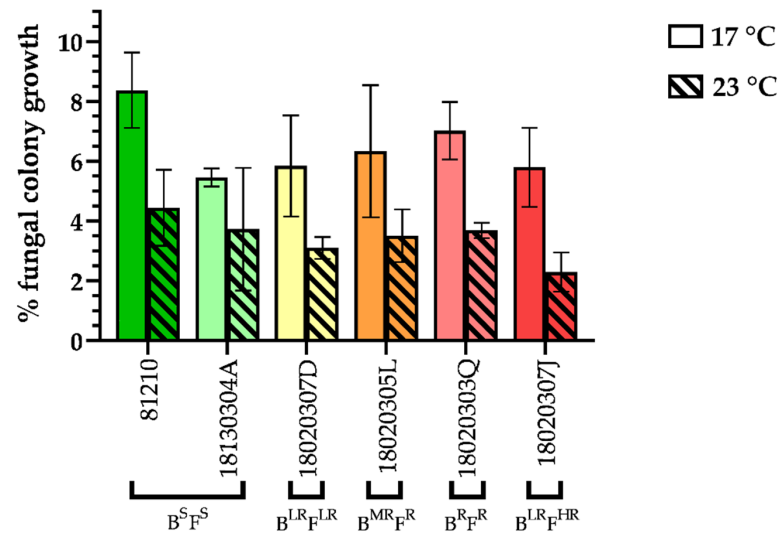

Figure 3. Percentage of fungal colony growth, starting from a single spore and covering the surface of a zucchini cotyledon. P. xanthii isolates with different SDHI phenotypes (sensitive (S) and low resistance (LR), moderate resistance (MR), resistant (R) and high resistance (HR) to boscalid (B) or fluopyram (F)) were incubated at $17^{\circ} \mathrm{C}$ and $23^{\circ} \mathrm{C}$ for 15 and 30 days, respectively. 


\subsection{LAMP Technique}

\subsubsection{Primer Design and Optimization of Lamp Reactions}

Four sets of primers, with two to detect $P$. xanthii SDHI-resistant isolates carrying the A86V amino acid change and two to detect the G151R substitution, were designed and tested. In the first case, both sets of primers (Set1 and Set2) were able to amplify the A86V-mutated isolate (19020304D) at $65^{\circ} \mathrm{C}$ in $22 \mathrm{~min}$, and thus we selected Set 1 for further experiments. In the case of the G151R sets, only one of them (Set4) was able to generate positive results using DNA from the resistant isolate (18020307I) at $65{ }^{\circ} \mathrm{C}$ in $30 \mathrm{~min}$. After that, the optimization of the LAMP reactions to detect both amino acid changes was performed. With this objective, three variables were checked: temperature, time, and primer concentrations. With respect to temperature and time, temperatures from $60.5^{\circ} \mathrm{C}$ to $69.5^{\circ} \mathrm{C}$ were tested over a 30-min period using the primer concentrations previously used in other studies $(1.6 \mu \mathrm{M}$ each of FIP and BIP, $0.2 \mu \mathrm{M}$ each of F3 and B3; [11]). In relation to Set1, the temperature of $65^{\circ} \mathrm{C}$ was selected because positive results were obtained in less time (22 $\mathrm{min}$ ) using DNA from the A86V-resistant isolate (Table 6). Regarding Set4, a shorter time (24 min and $30 \mathrm{~s}$ ) to obtain positive results was observed at $62.7^{\circ} \mathrm{C}$ (Table 6). For both sets of primers, no results were obtained at $67.1^{\circ} \mathrm{C}$ and $69.5^{\circ} \mathrm{C}$. The melting temperature $(\mathrm{T})$ was similar (approximately $87^{\circ} \mathrm{C}$ ) for both sets at the different study temperatures, indicating the absence of contamination (Table 6). Once the optimal temperature was determined, and to decrease the amplification time, a higher concentration of the FIP and BIP primers was tested. For Set1, the concentrated primers were able to decrease the amplification time from 22 to $16 \mathrm{~min}$; for Set4, it was reduced from $24 \mathrm{~min}$ and $30 \mathrm{~s}$ to $21 \mathrm{~min}$ and $30 \mathrm{~s}$.

\subsubsection{Specificity of LAMP Using Different Fungal Species}

Genomic DNA isolated from different fungal species (B. cinerea, D. bryoniae, E. diffusa, M. phaseolina and P. aphanis) was used to confirm the specificity of the LAMP assay. In addition, the sensitive P. xanthii isolate (SF9) and the SDHI-resistant isolates (19020304D and 18020307I) were also included. The LAMP reactions were performed using the optimized conditions described previously. No amplifications were obtained in the tubes containing sterile distilled water and the tubes with DNA extracted from the phytopathogenic fungi B. cinerea, D. bryoniae, E. diffusa, M. phaseolina, P. aphanis and the P. xanthii SDHI-sensitive isolate SF9. The LAMP reactions were positive (amplified product) in tubes containing genomic DNA from the $19020304 \mathrm{D}$ isolate (A86V present) at $65^{\circ} \mathrm{C}$ in $15 \mathrm{~min}$ and $45 \mathrm{~s}$ for Set1 and the $18020307 \mathrm{I}$ isolate, carrying the G151R amino acid change, at $62.7^{\circ} \mathrm{C}$ in $20 \mathrm{~min}$ and $30 \mathrm{~s}$ for Set4. The melting temperature was consistent with the positive controls.

\subsubsection{Repeatability of the LAMP Reaction}

To confirm the reliability of the LAMP technique, a total of 14 P. xanthii isolates (four sensitive and 10 SDHIs-resistant), which were previously characterized in in vitro fungicide sensitivity assays and with a fragment of the sequenced SdhC subunit, were used. To characterize the A86V allele, seven isolates were included: $18020303 \mathrm{~T}\left(\mathrm{~B}^{\mathrm{R}} \mathrm{F}^{\mathrm{R}}\right), 18020305 \mathrm{~L}\left(\mathrm{~B}^{\mathrm{MR}} \mathrm{F}^{\mathrm{R}}\right)$, $18030306 \mathrm{D}\left(\mathrm{B}^{\mathrm{MR}} \mathrm{F}^{\mathrm{MR}}\right), 18030306 \mathrm{M}\left(\mathrm{B}^{\mathrm{MR}} \mathrm{F}^{\mathrm{R}}\right), 18020307 \mathrm{~K}\left(\mathrm{~B}^{\mathrm{LR}} \mathrm{F}^{\mathrm{HR}}\right), 18020307 \mathrm{~L}\left(\mathrm{~B}^{\mathrm{LR}} \mathrm{F}^{\mathrm{R}}\right)$, and $19020304 \mathrm{D}\left(\mathrm{B}^{\mathrm{LR}} \mathrm{F}^{\mathrm{R}}\right)$. To check the absence/presence of the G151R amino acid change, two P. xanthii isolates, obtained during the SDHI monitoring studies in 2018-2019, 18030306K $\left(\mathrm{B}^{\mathrm{R}} \mathrm{F}^{\mathrm{LR}}\right)$ and $18020307 \mathrm{I}\left(\mathrm{B}^{\mathrm{R}} \mathrm{F}^{\mathrm{S}}\right)$, were studied. As expected, only the resistant isolates showed amplification with their corresponding set of primers (Table 6). All the isolates carrying the A86V mutation showed results between 14 and $16 \mathrm{~min}$. The G151R isolates amplified in approximately $22 \mathrm{~min}$. The $\mathrm{T}$ temperature was similar in all cases for both set of primers, at approximately $85^{\circ} \mathrm{C}$, indicating absence of the sample contamination (Table 6). Negative LAMP results (no amplification) were obtained using DNA extracted from the sensitive isolates (MR03, SF9, SF60 and 311271) and tubes without DNA as template (Table 6). 
Table 6. Tests and results of LAMP assay for detecting the amino acid changes A86V and G151R in P. xanthii.

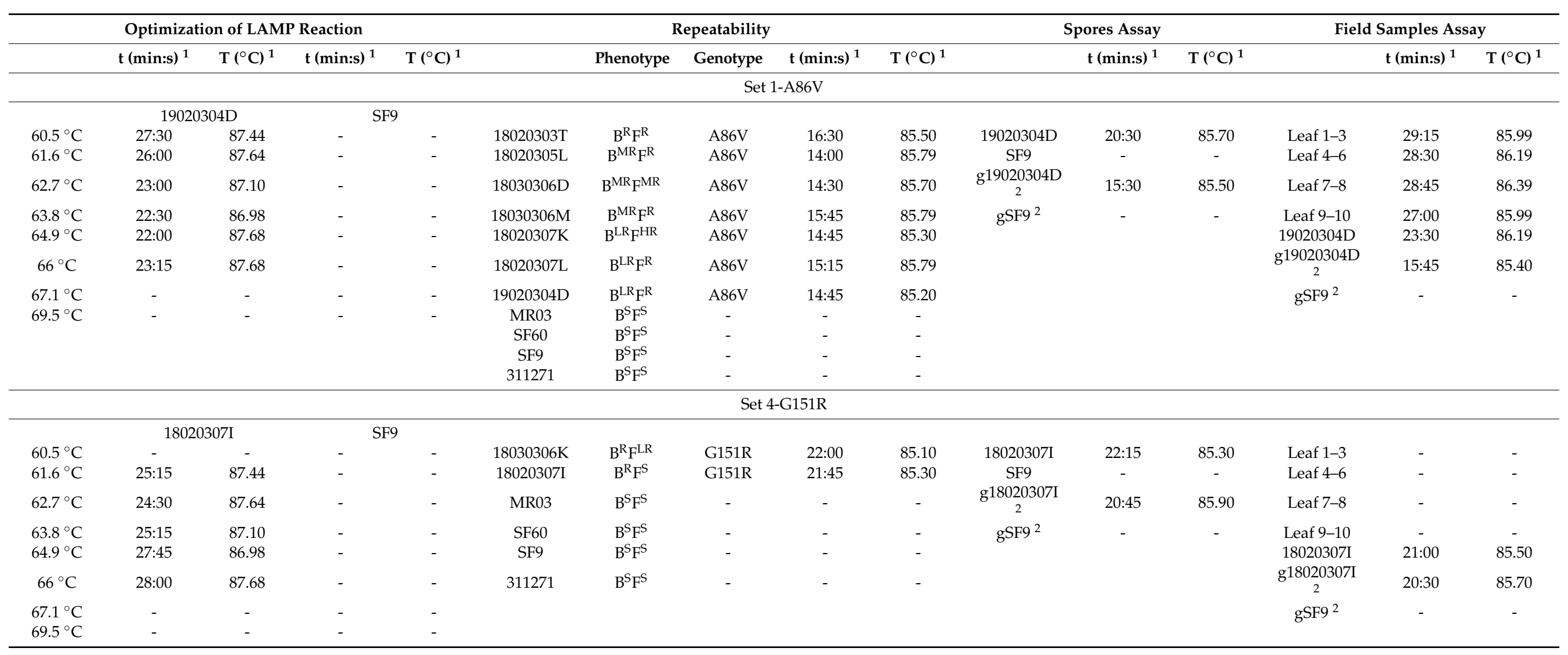

${ }^{1} \mathrm{t}$ refers to the amplification time in minutes:seconds and $\mathrm{T}$ to the melting temperature in Celsius, ${ }^{2}$ Genomic DNA used extracted using conventional methods. For negative results, - is indicated. 


\subsubsection{Optimization of LAMP Assay Using Spores}

Zucchini cotyledons infected with spores from SDHI-sensitive (SF9) and SDHI-resistant isolates carrying A86V (19020304D) and G151R (18020307I) amino acid changes were used. DNA was extracted with a quick assay using spores (approximately $3 \times 10^{6}$ ) and with a conventional method. For Set1 (A86V), only the SDHI-resistant isolate 19020304D showed an amplification product using DNA extracted from spores and with conventional methods at 20 and $15 \mathrm{~min}$, respectively. These results were consistent with those of Set4 (G151R), for which the amplification product was detected in the G151R-resistant isolate (18020307I) at 22 and 20 min using DNA extracted from spores or conventional methods, respectively. In both cases, the melting temperature was similar to the positive control, at approximately $85^{\circ} \mathrm{C}$ (Table 6). For both sets, no SdhC amplifications were observed in tubes containing DNA from the SDHI-sensitive isolate (SF9) or when using sterile distilled water as a template.

\subsubsection{Testing LAMP Assay in Field Samples}

Once the LAMP assay was optimized using a low number of spores, an assay was performed to confirm the reliability of the technique using plant material collected directly from the field. For that purpose, 10 powdery mildew-infected leaves were used to obtain DNA from spores and used for the LAMP reaction with the two primer sets. The results showed that $P$. xanthii isolates carrying only A86V were present in all samples tested, indicating resistance to SDHI fungicides. For Set1, the amplification products were obtained from 27 to $29 \mathrm{~min}$ in the different samples. The melting temperature was approximately $85^{\circ} \mathrm{C}$ for all positive samples, indicating that the amplification product was not contaminated (Table 6). Notably, when fungal biomass obtained from the same leaves was tested using the in vitro leaf-disk sensitivity assay, positive results were obtained because the bulk conidial mass was able to grow at least at $50 \mathrm{mg} / \mathrm{L}$ of both boscalid and fluopyram, confirming the result obtained using the LAMP technique.

\section{Discussion}

The study of the fungicide resistance phenomenon is an essential step to avoiding the losses associated with fungal diseases in the field. The purpose of this work was to study, for the first time in Spain, the fungicide resistance situation of $P$. xanthii populations to SDHI fungicides, one of the families with relatively more active ingredients registered in recent years. For this purpose, several experiments, such as in vitro and in vivo fungicide sensitivity studies, analyses of the point mutations involved in resistance to boscalid and fluopyram, including its rapid molecular diagnosis through the LAMP technique and, lastly, the possible fitness cost associated with SDHI resistance, were performed.

The SDHI resistance monitoring studies performed during the 2018 and 2019 cucurbit production seasons showed that almost half of the isolates analysed had reduced sensitivity to boscalid (37.9\%) and fluopyram (44.0\%). The results varied in each test province: Granada and Malaga showed an absence or low levels of resistance, while Almeria and Murcia revealed high frequencies of resistant isolates (Almeria, $51.1 \%$ to boscalid and $57.4 \%$ to fluopyram; Murcia, $55.6 \%$ and $66.9 \%$ to boscalid and fluopyram, respectively). Moreover, the level of SDHI resistance in these two provinces usually increased from one year to another. In Almeria, the frequency of boscalid resistance increased from $42.9 \%$ to $59.4 \%$, and for fluopyram it increased from $44.4 \%$ to $70.3 \%$. With respect to Murcia, except for boscalid-resistant isolates, which remained at approximately $55 \%$, the frequency of fluopyram resistance increased from $56.3 \%$ to $74.5 \%$. According to the information provided by the growers, this increase could be due to the use of these fungicides to control other fungal diseases (anthracnose, Alternaria leaf blight, grey mould, leaf spot, and Sclerotinia stem rot). In addition, in the provinces of Granada and Malaga, which showed an absence or very low levels of resistance, a good fungicide management application, meaning the alternation between fungicides with different modes of action, and between single- and multisite fungicides, was performed. 
Our results are supported by other studies in which high levels of SDHI resistance were described in several fungal pathogens, including P. xanthii, B. cinerea, A. alternata, A. solari, D. bryoniae, C. cassiicola and P. teres collected from fields where these fungicides have been frequently applied. In relation to P. xanthii, similar frequencies were described for boscalid in the American and Japanese populations of this pathogen, with 44 and $45.96 \%$ resistant isolates, respectively $[30,58]$. Different studies on $B$. cinerea showed approximately $50 \%$ boscalid-resistant isolates for the total population in Greece, Germany, and Spain $[23,27,59]$. With regard to a study developed in several strawberry fields in Spain, an increase from $5.3 \%$ to $10.4 \%$ in fluopyram-resistant isolates was observed in the B. cinerea population collected between 2015 and 2016 [27]. With reference to A. alternata, several studies in pistachio orchards in the USA also documented high percentages of SDHI-resistant isolates $[19,60]$ and, in addition, an increasing trend over the years in farms where boscalid had been used extensively [16,61]. High frequencies of boscalid-resistant isolates have been described for A. solani (75\%), D. bryoniae (79.6\%), and C. cassiicola (48.9\%) in monitoring studies performed in SDHI-treated fields from the USA and Japan [62-64]. Regarding $P$. teres, in a very complete study performed in several European countries, similar levels of resistance to those presented in this study, namely $44 \%$ for boscalid and $47 \%$ for fluopyram, were obtained for the isolates sampled from Germany in 2013 and 2014 [31]. Moreover, the overall percentage of SDHI-resistant isolates in all the studied countries increased from $1.2 \%$ to $25 \%$ in 2012 and 2013, respectively [31].

According to their growth in in vitro leaf-disc assays, our results showed that the Spanish P. xanthii population could be divided into four different levels of resistance; however, when some representative isolates were tested in planta, all the resistant phenotypes, regardless of the resistance category, were able to develop disease in plants sprayed with the field doses of boscalid and fluopyram $(100 \mathrm{mg} / \mathrm{L})$, showing the same colony development for all of them. The differences in SDHI applications may explain the different results observed in in vitro and in vivo assays. For P. xanthii, the laboratory approach for fungicide sensitivity tests is based on the use of leaf discs in direct contact with the fungicide solution during a period, which creates a larger exposure to the fungicide. This characteristic could make the final concentration of the fungicide in the plant tissue higher and make it possible to distinguish different categories of phenotypes. However, in the field, when these fungicides are applied, after entering the plant fungicides are transferred to different parts by the xylem due to acropetal phytomobility, making the concentration lower than that in leaf discs; therefore, all phenotypes (LR, MR, R and HR) were capable of developing powdery mildew disease under the conditions of these experiments [65]. Similar discrepancies have also been documented for another biotrophic fungus, the grape powdery mildew Erysiphe necator [66]. In that study, a leaf disc sporulation assay was conducted to establish sensitivity to quinoxyfen, with some isolates showing decreased sensitivity; however, when the results were contrasted with a quantitative assay based on germ tube elongation inhibition, the same isolates were completely inhibited by quinoxyfen [66]. Differences between resistant phenotypes in in vitro and in vivo assays were also observed in experiments on $B$. cinerea. Isolates that were considered moderately resistant and resistant to cyprodinil in the in vitro assay developed grey mould disease at the same levels in infected cyprodinil-treated fruits [67]. These results were confirmed in other studies in which $B$. cinerea isolates, which had moderate and higher resistance levels in in vitro assays for cyprodinil and iprodione, infected fruits with the same degree of virulence when treated with these fungicides $[68,69]$.

Resistance to SDHI fungicides is conferred by point mutations in the three subunits, which conform to the ubiquinone binding site (SdhB, SdhC and SdhD) of mitochondrial complex II. Several amino acid changes have been described in different fungal species; [15]; however, little is known about powdery mildew fungi, with only three research studies, two on E. necator and one on P. xanthii. In E. necator, the amino acid change H242R/Y in ShdB correlated with boscalid and fluopyram resistance, and the amino acid change G169D in SdhD explained the low sensitivity to fluxapyroxad and fluopyram [70,71]. With respect to 
P. xanthii, a recent study documented some mutations in the subunits SdhD and SdhC. The amino acid change S121P in SdhD provided moderate levels of resistance to isopyrazam, penthiopyrad and pyraziflumid, while high levels of resistance to the same fungicides were conferred by the changes H137R, in the same subunit, and the changes G151R and G172D in SdhC. Lastly, high levels of resistance to isofetamid were associated with the presence of the amino acid change A86V in subunit SdhC [57]. In our study, this point mutation was observed in all P. xanthii isolates with resistance to boscalid and fluopyram but also in isolates that were only resistant to fluopyram, independent of the resistant phenotype observed in vitro. However, the amino acid substitution G151R was also observed in two $P$. xanthii isolates that presented resistance to boscalid and remained sensitive or low in resistance to fluopyram. Although boscalid and fluopyram were not tested in the work of Miyamoto and collaborators, other studies have explained the resistance to these two fungicides with the homologous position of these amino acid changes in other phytopathogenic fungi [72]. For example, in a study on the phytopathogenic fungus Zymoseptoria tritici, the substitution $\mathrm{A} 84 \mathrm{~V}$ was related to isofetamid and fluopyram resistance [73]. Furthermore, in a study by Scalliet and collaborators (2012), this change interacted with the fluopyram aliphatic linker, which is a characteristic of this compound [74]. In B. cinerea, A86V has been associated with resistance to fluopyram, but sensitivity to boscalid [75]. In C. cassiicola, the substitution S73P provided moderate levels of resistance to fluopyram [50]. In relation to the amino acid change G151R, the equivalence change G150R has been described in one Sclerotinia homoeocarpa isolate, which was resistant to several SDHI fungicides, such as boscalid, fluxapyroxad, isofetamid and penthiopyrad, but not to fluopyram [76].

Although the most frequent described mechanism of resistance is the presence of point mutations in the corresponding target genes, other mechanisms (detoxification, overexpression of the target genes or the implication of drug efflux transporters) could be involved. In our study, most of the P. xanthii isolates, which presented the amino acid change A86V, had cross-resistance to boscalid and fluopyram; however, eleven isolates with the same amino acid change were sensitive to boscalid and resistant to fluopyram. Therefore, could an alternative mechanism be involved in the SDHI resistance? The possibility was also raised in Z. tritici when several fluopyram- and isofetamid-resistant isolates did not carry any point mutations in the different Sdh subunits [73]. In other studies, Z. tritici isolates highly resistant to DMI fungicides and poorly resistant to QoIs and SDHIs presented overexpression in the BcMFS1 gene, which encodes a major facilitator transporter (MFS), a superfamily of transporters involved in a drug efflux system [77,78]. In the dollar spot fungus $S$. homoeocarpa, the overexpression of two ATP-binding cassette (ABC) drug efflux transporters (ShPDR1 and ShartD) explained the reduced sensitivity to nonrelated, site-specific fungicides, including boscalid (SDHI), iprodione (dicarboxamide) and propiconazole (DMI) [79]. In the same pathogen, the amino acid substitution M853T in the transcription factor ShDR1 was responsible for the overexpression of the ABC transporter, resulting in fungicide resistance to propiconazole (DMI fungicide), iprodione (dicarboximide) and boscalid (SDHI fungicide; [80]). In the wheat powdery mildew B. graminis $\mathrm{f}$. sp. tritici, a BgABC1 gene was related to the overexpression of the $\mathrm{ABC}$ transporter in seeds treated with the DMI fungicide triadimefon [81]. In relation to P. xanthii, there is no information about the correlation of ABC or MFS transporter expression and fungicide resistance. However, the genome of this organism has recently been published [52] and the implication of some of these transporter superfamilies in resistance to different fungicides, including SDHIs, could be explored in future studies.

An important part of resistance analysis is the biological cost that may be associated with different processes involved in the natural survival of the pathogen. The characterization of this cost is essential to predicting the behaviour of the entire pathogen population and to implementing disease control strategies in the future [82]. This possible biological cost is usually studied, among other approaches, based on sporulation, mycelial growth or the aggressiveness of the study isolates $[83,84]$. The results observed in the present study showed no fitness cost in a collection of representative SDHI-sensitive and SDHI- 
resistant $P$. xanthii isolates on mycelial development and spore germination. In studies on other phytopathogenic fungi, such as A. alternata, similar results were obtained, and no differences were observed between germination, hyphal development, sporulation or virulence when boscalid-sensitive and resistant isolates were compared [61]. In addition, the boscalid resistance levels did not decrease after various subcultures in the absence of this fungicide, indicating the stability of resistance without selection pressure [61]. Similar results were observed in $A$. solani, with no significant differences in spore germination, mycelial expansion or aggressiveness in in vivo tests among sensitive and resistant isolates to several fungicides (anilinopyrimidine [AP], QoI and SDHI, [84]).

Fungicide resistance monitoring studies on cucurbit powdery mildew are usually performed using bioassays with plants, meaning there is a great investment of time and material [34]. However, when the mechanism of resistance is known and is caused by point mutations in the corresponding target gene, the detection of the different phenotypes can be performed using molecular methods, making it a better solution than time-consuming bioassays. In recent years, the LAMP technique has become an interesting alternative that offers the possibility of obtaining results from field samples within a few hours, and is an attractive tool to use in resistance monitoring studies. In the present study, this technique was developed to detect the two-point mutations (A86V and G151R) observed in the SDHI-resistant population of $P$. xanthii in less than $40 \mathrm{~min}$, complementing a previous study on the detection of MBC-resistant isolates carrying the E198A substitution in cucurbit powdery mildew [10]. All this information will help to provide faster responses to growers regarding the effectiveness of these fungicides in fields affected with this disease.

The registration of SDHI fungicides, resistance to this class of fungicides in P. xanthii has been described in several countries [85]. Moreover, high levels of resistance to other nonrelated fungicides have been reported previously in this pathogen in Spain and in other parts of the world [7-9,57,86-89]. In 2020, the European Committee approved the European Green Deal, which proposes the promotion of an efficient use of resources, the restoration of biodiversity, and the reduction of pollution, toward a climate-neutral Europe by 2050. This change would be achieved through a series of objectives, including reducing pesticide use by 50\% [90]. This reduction is being reflected in Spain and, since 2017, five active substances belonging to three different chemical families [cyproconazole, flutriafol and hexaconazole (DMIs), kresoxim-methyl (QoIs) and quinoxyfen (aza-naphthalenes)] have been withdrawn from use. Due to the imminent reduction in chemical tools to control fungal diseases, the time needed to generate new substances from the phytosanitary sector (with a mean of ten years), and the rapid development of resistance by this and other fungal plant pathogens, it is fundamental to perform monitoring studies for testing the efficacy of each fungicide to increase the effectiveness of these compounds over time and to slow down the emergence of resistance. The implementation of integrated pest management (IPM) with, among others, the alternation between single-site and multisite fungicides, changes the mode of action between single-site fungicide families and is a good practice in the field. This may control the rise of resistance to SDHI and other families of fungicides, which is currently necessary.

Author Contributions: Conceptualization, A.d.V., A.P.-G. and D.F.-O.; methodology, A.V.-F. and Á.P.; software, Á.P. and L.R.-J.; validation, A.V.-F. and L.R.-J.; formal analysis, A.V.-F. and Á.P.; investigation, A.V.-F. and L.R.-J.; resources, A.d.V., A.P.-G. and D.F.-O.; data curation, A.V.-F. and Á.P.; writing-original draft preparation, A.V.-F. and D.F.-O.; writing-review and editing, A.d.V., D.F.-O. and A.P.-G.; visualization, A.d.V. and A.V.-F.; supervision, D.F.-O. and A.P.-G.; project administration, A.P.-G.; funding acquisition, A.P.-G. and D.F.-O. All authors have read and agreed to the published version of the manuscript.

Funding: This study was supported by a grant from the "Agencia Estatal de Investigación (AEI)" (AGL2016-76216-C2-1-R), cofinanced by FEDER funds (European Union). A. Vielba-Fernández was supported by a PhD fellowship (FPU17/00583) from the Ministerio de Ciencia, Innovación y Universidades. 
Acknowledgments: The authors kindly acknowledge the excellent technical support provided by Irene Linares, Virginia Mota and Yandira Morales.

Conflicts of Interest: The authors declare no conflict of interest.

\section{References}

1. Anuario de Estadística. Estadísticas Agrarias y Alimentación. Capítulo 07: Superficies y Producciones de Cultivos. Hortalizas. 2019. Available online: https://www.mapa.gob.es/es/estadistica/temas/publicaciones/anuario-de-estadistica/2019/default. aspx? parte $=3 \&$ capitulo $=07 \&$ grupo $=6$ (accessed on 18 June 2021).

2. Sitterly, W.R. Powdery mildews of cucurbits. In The Powdery Mildews; APS Press: St. Paul, MN, USA, 1978; pp. $359-379$.

3. Pérez-García, A.; Romero, D.; Fernández-Ortuño, D.; López-Ruiz, F.; De Vicente, A.; Torés, J.A. The powdery mildew fungus Podosphaera fusca (synonym Podosphaera xanthii), a constant threat to cucurbits. Mol. Plant Pathol. 2009, 10, 153-160. [CrossRef] [PubMed]

4. Braun, U.; Cook, R.T.A.; Inman, A.J.; Shin, H.D. The taxonomy of the powdery mildew fungi. In The Powdery Mildews: A Comprehensive Treatis, 1st ed.; Richard, R., Bélanger, R.R., Bushnell, W.R., Dik, A.J., Carver, T.L.W., Eds.; American Phytopathological Society (APS Press): St. Paul, MN, USA, 2001; pp. 13-55.

5. Torés, J.A.; Cánovas, I.; Velasco, M.V. A note on Sphaerotheca fuliginea (Schlecht. ex Fr.) Poll., causal agent of powdery mildew on Cucurbitaceae in the coastal areas of Malaga and Almeria. Investig. Agrar. Prod. Prot. Veg. 1990, 5, 475-479.

6. Del Pino, D.; Olalla, L.; Pérez-García, A.; Rivera, M.E.; García, S.; Moreno, R.; de Vicente, A.; Torés, J.A. Occurrence of races and pathotypes of cucurbit powdery mildew in southeastern Spain. Phytoparasitica 2002, 30, 459-466. [CrossRef]

7. Fernández-Ortuño, D.; Pérez-García, A.; López-Ruiz, F.; Romero, D.; de Vicente, A.; Torés, J.A. Occurrence and distribution of resistance to QoI fungicides in populations of Podosphaera fusca in south central Spain. Eur. J. Plant Pathol. 2006, 115, $215-222$. [CrossRef]

8. López-Ruiz, F.J.; Pérez-García, A.; Fernández-Ortuño, D.; Romero, D.; García, E.; de Vicente, A.; Brown, J.K.; Torés, J.A. Sensitivities to DMI fungicides in populations of Podosphaera fusca in south central Spain. Pest Manag. Sci. 2010, 66, 801-808. [CrossRef]

9. Bellón-Gómez, D.; Vela-Corcía, D.; Pérez-García, A.; Torés, J.A. Sensitivity of Podosphaera xanthii populations to anti-powderymildew fungicides in Spain. Pest. Manag. Sci. 2015, 71, 1407-1413. [CrossRef]

10. Vielba-Fernández, A.; de Vicente, A.; Pérez-García, A.; Fernández-Ortuño, D. Monitoring methyl benzimidazole carbamateresistant isolates of the cucurbit powdery mildew pathogen, Podosphaera xanthii, using loop-mediated isothermal amplification. Plant Dis. 2019, 103, 1515-1524. [CrossRef]

11. Vielba-Fernández, A.; Bellón-Gómez, D.; Torés, J.A.; de Vicente, A.; Pérez-García, A.; Fernández-Ortuño, D. Heteroplasmy for the Cytochrome b Gene in Podosphaera xanthii and its Role in Resistance to QoI Fungicides in Spain. Plant Dis. 2018, 102, 1599-1605. [CrossRef] [PubMed]

12. FRAC Code List. 2021. Available online: https:/ / www.frac.info/docs/default-source/publications/frac-code-list/frac-code-list2021--final.pdf?sfvrsn=f7ec499a_2 (accessed on 18 June 2021).

13. Keon, J.P.; White, G.A.; Hargreaves, J.A. Isolation, characterization, and sequence of a gene conferring resistance to the systemic fungicide carboxin from the maize smut pathogen, Ustilago maydis. Curr. Genet. 1991, 19, 475-481. [CrossRef] [PubMed]

14. Hägerhäll, C. Succinate: Quinone oxidoreductases: Variations on a conserved theme. Biochim. Biophys. Acta Bioenerg. 1997, 1320, 107-141. [CrossRef]

15. Sang, H.; Lee, H.B. Molecular mechanisms of Succinate Dehydrogenase Inhibitor resistance in phytopathogenic fungi. Res. Plant Dis. 2020, 26, 1-7.

16. Avenot, H.F.; Sellam, A.; Karaoglanidis, G.; Michailides, T.J. Characterization of mutations in the iron-sulphur subunit of Succinate Dehydrogenase correlating with boscalid resistance in Alternaria alternata from California pistachio. Phytopathology 2008, 98 , 736-742. [CrossRef]

17. Avenot, H.F.; Sellam, A.; Michailides, T.J. Characterization of mutations in the membrane-anchored subunits AaSDHC and AaSDHD of succinate dehydrogenase from Alternaria alternata isolates conferring field resistance to the fungicide boscalid. Plant Pathol. 2009, 58, 1134-1143. [CrossRef]

18. Avenot, H.F.; van den Biggelaar, H.; Morgan, D.P.; Moral, J.; Joosten, M.; Michailides, T.J. Sensitivities of baseline isolates and boscalid-resistant mutants of Alternaria alternata from pistachio to fluopyram, penthiopyrad, and fluxapyroxad. Plant Dis. 2014, 98, 197-205. [CrossRef] [PubMed]

19. Avenot, H.F.; Luna, M.; Michailides, T.J. Phenotypic and molecular characterization of resistance to the SDHI fungicide fluopyram in populations of Alternaria alternata from pistachio orchards in California. Crop Prot. 2019, 124, 104838. [CrossRef]

20. Yang, J.H.; Brannen, P.M.; Schnabel, G. Resistance in Alternaria alternata to SDHI fungicides causes rare disease outbreak in peach orchards. Plant Dis. 2015, 99, 65-70. [CrossRef] [PubMed]

21. Fan, Z.; Yang, J.-H.; Fan, F.; Luo, C.-X.; Schnabel, G. Fitness and competitive ability of Alternaria alternata field isolates with resistance to SDHI, QoI, and MBC fungicides. Plant Dis. 2015, 99, 1744-1750. [CrossRef] [PubMed]

22. Leroux, P.; Gredt, M.; Leroch, M.; Walker, A.-S. Exploring mechanisms of resistance to respiratory inhibitors in field strains of Botrytis cinerea, the causal agent of gray mold. Appl. Environ. Microbiol. 2010, 76, 6615-6630. [CrossRef] 
23. Veloukas, T.; Leroch, M.; Hahn, M.; Karaoglanidis, G.S. Detection and molecular characterization of boscalid-resistant Botrytis cinerea isolates from strawberry. Plant Dis. 2011, 95, 1302-1307. [CrossRef]

24. Yin, Y.N.; Kim, Y.K.; Xiao, C.L. Molecular characterization of boscalid resistance in field isolates of Botrytis cinerea from apple. Phytopathology 2011, 101, 986-995. [CrossRef]

25. Amiri, A.; Heath, S.M.; Peres, N.A. Resistance to fluopyram, fluxapyroxad, and penthiopyrad in Botrytis cinerea from strawberry. Plant Dis. 2014, 98, 532-539. [CrossRef]

26. Hu, M.-J.; Fernández-Ortuño, D.; Schnabel, G. Monitoring resistance to SDHI fungicides in Botrytis cinerea from strawberry fields. Plant Dis. 2016, 100, 959-965. [CrossRef]

27. Fernández-Ortuño, D.; Pérez-García, A.; Chamorro, M.; de la Peña, E.; de Vicente, A.; Torés, J.A. Resistance to the SDHI fungicides boscalid, fluopyram, fluxapyroxad, and penthiopyrad in Botrytis cinerea from commercial strawberry fields in Spain. Plant Dis. 2017, 101, 1306-1313. [CrossRef]

28. Fungicide Resistance Action Committee. List of Species Resistant to SDHIs 2015. Available online: https://www.frac.info/docs/ default-source/working-groups/sdhi-references/list-of-species-resistant-to-sdhis-april-2015.pdf?sfvrsn=2d144a9a_2 (accessed on 18 June 2021).

29. Avenot, H.F.; Thomas, A.; Gitaitis, R.D.; Langston, D.B., Jr.; Stevenson, K.L. Molecular characterization of boscalid- and penthiopyrad-resistant isolates of Didymella bryoniae and assessment of their sensitivity to fluopyram. Pest Manag. Sci. 2012, 68, 645-651. [CrossRef]

30. Miyamoto, T.; Ishii, H.; Tomita, Y. Occurrence of boscalid resistance in cucumber powdery mildew in Japan and molecular characterization of the iron-sulfur protein of succinate dehydrogenase of the causal fungus. J. Gen. Plant Pathol. 2010, 76, 261-267. [CrossRef]

31. Rehfus, A.; Miessner, S.; Achenbach, J.; Strobel, D.; Bryson, R.; Stammler, G. Emergence of succinate dehydrogenase inhibitor resistance of Pyrenophora teres in Europe. Pest Manag. Sci. 2016, 72, 1977-1988. [CrossRef] [PubMed]

32. Mallik, I.; Arabiat, S.; Pasche, J.S.; Bolton, M.D.; Patel, J.S.; Gudmestad, N.C. Molecular characterization and detection of mutations associated with resistance to succinate dehydrogenase inhibiting fungicides in Alternaria solani. Phytopathology 2014, 104, 40-49. [CrossRef] [PubMed]

33. Miyamoto, T.; Hayashi, K.; Okada, R.; Wari, D.; Ogawara, T. Resistance to succinate dehydrogenase inhibitors in field isolates of Podosphaera xanthii on cucumber: Monitoring, cross-resistance patterns and molecular characterization. Pestic. Biochem. Phys. 2020, 169, 104646. [CrossRef] [PubMed]

34. Hollomon, D.W.; Ishii, H. Monitoring resistance using molecular methods. In Fungicide Resistance in Plant Pathogens: Principles and a Guide to Practical Management, 1st ed.; Hollomon, D.W., Ishii, H., Eds.; Springer: Tokyo, Japan, 2015; pp. $295-309$.

35. Lichtemberg, P.S.F.; Luo, Y.; Doussoulin, H.; Michailides, T.J. Using Allele-specific PCR for detecting multiple amino acid substitutions associated with SDHI resistance in Alternaria alternata causing Alternaria late blight in pistachio. J. Appl. Microbiol. 2018, 67, 506-512. [CrossRef] [PubMed]

36. De Miccolis Angelini, R.M.; Masiello, M.; Rotolo, C.; Pollastro, S.; Faretra, F. Molecular characterisation and detection of resistance to succinate dehydrogenase inhibitor fungicides in Botryotinia fuckeliana (Botrytis cinerea). Pest Manag. Sci. 2014, 70, 1884-1893. [CrossRef]

37. Lee, J.; Elliott, M.; Kim, M.; Yamada, T.; Jung, G. A rapid molecular detection system for SdhB and SdhC point mutations conferring differential SDHI resistance in populations of Clarireedia. Plant Dis. 2020, 105, 660-666. [CrossRef]

38. Samaras, A.; Madesis, P.; Karaoglanidis, G.S. Detection of sdhB gene mutations in SDHI-resistant isolates of Botrytis cinerea using High Resolution Melting (HRM) analysis. Front. Microbiol. 2016, 7, 1815. [CrossRef] [PubMed]

39. Chatzidimopoulos, M.; Ganopoulos, I.; Madesis, P.; Vellios, E.; Tsaftaris, A.; Pappas, A.C. High-resolution melting analysis for rapid detection and characterization of Botrytis cinerea phenotypes resistant to fenhexamid and boscalid. Plant Pathol. 2014, 63, 1336-1343. [CrossRef]

40. Notomi, T.; Okayama, H.; Masubuchi, H.; Yonekawa, T.; Watanabe, K.; Amino, N.; Hase, T. Loop-mediated isothermal amplification of DNA. Nucleic Acids Res. 2000, 28, e63. [CrossRef]

41. Duan, Y.; Zhang, X.; Ge, C.; Wang, Y.; Cao, J.; Jia, X.; Wang, J.; Zhou, M. Development and application of loop-mediated isothermal amplification for detection of the F167Y mutation of carbendazim-resistant isolates in Fusarium graminearum. Sci. Rep. 2014, 4, 7094. [CrossRef] [PubMed]

42. Duan, Y.B.; Yang, Y.; Wang, J.X.; Liu, C.C.; He, L.L.; Zhou, M.G. Development and application of loop-mediated isothermal amplification for detecting the highly benzimidazole-resistant isolates in Sclerotinia sclerotiorum. Sci. Rep. 2015, 5, 17278. [CrossRef] [PubMed]

43. Liu, Y.H.; Yuan, S.K.; Hu, X.R.; Zhang, C.Q. Shift of sensitivity in Botrytis cinerea to benzimidazole fungicides in strawberry greenhouse ascribing to the rising-lowering of E198A subpopulation and its visual, on-site monitoring by loop-mediated isothermal amplification. Sci. Rep. 2019, 9, 11644. [CrossRef] [PubMed]

44. Fan, F.; Hahn, M.; Li, G.-Q.; Lin, Y.; Luo, C.-X. Rapid detection of benzimidazole resistance in Botrytis cinerea by loop-mediated isothermal amplification. Phytopathol. Res. 2019, 1, 10. [CrossRef]

45. Zhou, D.; Guo, J.; Xu, L.; Gao, S.; Lin, Q.; Wu, Q.; Wu, L.; Que, Y. Establishment and application of a loop-mediated isothermal amplification (LAMP) system for detection of cry1Ac transgenic sugarcane. Sci. Rep. 2014, 4, 4912. [CrossRef] 
46. Goto, M.; Honda, E.; Ogura, A.; Nomoto, A.; Hanaki, K. Colorimetric detection of loop-mediated isothermal amplification reaction by using hydroxy naphthol blue. Biotechniques 2009, 46, 167-172. [CrossRef]

47. Tomita, N.; Mori, Y.; Kanda, H.; Notomi, T. Loop-mediated isothermal amplification (LAMP) of gene sequences and simple visual detection of products. Nat. Protoc. 2008, 3, 877-882. [CrossRef] [PubMed]

48. Tanner, N.A.; Zhang, Y.; Evans, T.C. Visual detection of isothermal nucleic acid amplification using pH-sensitive dyes. Biotechniques 2015, 58, 59-68. [CrossRef] [PubMed]

49. Fan, F.; Yin, W.X.; Li, G.Q.; Lin, Y.; Luo, C.X. Development of a LAMP method for detecting SDHI fungicide resistance in Botrytis cinerea. Plant Dis. 2018, 102, 1612-1618. [CrossRef] [PubMed]

50. Zhu, J.; Zhang, L.; Li, H.; Gao, Y.; Mu, W.; Liu, F. Development of a LAMP method for detecting the N75S mutant in SDHI-resistant Corynespora cassiicola. Anal. Biochem. 2020, 597, 113687. [CrossRef] [PubMed]

51. Álvarez, B.; Torés, J.A. Cultivo in vitro de Sphaerotheca fuliginea (Schlecht. ex Fr.), efecto de diferentes fuentes de carbono sobre su desarrollo. Bol. San. Veg. Plagas 1997, 23, 283-288.

52. Pérez-García, A.; Mingorance, E.; Rivera, M.E.; del Pino, D.; Romero, D.; Torés, J.A.; de Vicente, A. Long-term preservation of Podosphaera fusca using silica gel. J. Phytopathol. 2006, 154, 190-192. [CrossRef]

53. Polonio, Á.; Díaz-Martínez, L.; Fernández-Ortuño, D.; de Vicente, A.; Romero, D.; López-Ruiz, F.J.; Pérez-García, A. A hybrid genome assembly resource for Podosphaera xanthii, the main causal agent of powdery mildew disease in cucurbits. Mol. Plant Microbe Interact. 2021, 34, 319-324. [CrossRef] [PubMed]

54. Bellón-Gómez, D. Nuevas Perspectivas Moleculares y Agronómicas de la Resistencia a Fungicidas en Podospharea fusca. Ph.D. Thesis, University of Malaga, Malaga, Spain, 2014.

55. Vela-Corcía, D.; Bellón-Gómez, D.; López-Ruiz, F.; Torés, J.A.; Perez-Garcia, A. The Podosphaera fusca TUB2 gene, a molecular "Swiss Army knife" with multiple applications in powdery mildew research. Fungal Biol. 2014, 118, 228-241. [CrossRef]

56. Martínez-Cruz, J.; Romero, D.; de la Torre, F.N.; Fernández-Ortuño, D.; Torés, J.A.; de Vicente, A.; Pérez-García, A. The functional characterization of Podosphaera xanthii candidate effector genes reveals novel target functions for fungal pathogenicity. Mol. Plant Microbe Interact. 2018, 31, 914-931. [CrossRef]

57. Whelan, J.A.; Russell, N.B.; Whelan, M.A. A method for the absolute quantification of cDNA using real-time PCR. J. Immunol. Methods 2003, 278, 261-269. [CrossRef]

58. McGrath, M.T. Fungicide sensitivity in Podosphaera xanthii and efficacy for cucurbit powdery mildew in NY, USA, in 2003-2006. J. Plant Pathol. 2008, 90, 90.

59. Weber, R.W.; Entrop, A.-P.; Goertz, A.; Mehl, A. Status of sensitivity of Northern German Botrytis populations to the new SDHI fungicide fluopyram prior to its release as a commercial fungicide. J. Plant Dis. Prot. 2015, 122, 81-90. [CrossRef]

60. Avenot, H.F.; Michailides, T.J. Occurrence and Extent of Boscalid Resistance in Populations of Alternaria alternata from California Pistachio Orchards. Plant Dis. 2020, 104, 306-314. [CrossRef]

61. Avenot, H.F.; Michailides, T.J. Resistance to boscalid fungicide in Alternaria alternata isolates from pistachio in California. Plant Dis. 2007, 91, 1345-1350. [CrossRef]

62. Gudmestad, N.C.; Arabiat, S.; Miller, J.S.; Pasche, J.S. Prevalence and impact of SDHI fungicide resistance in Alternaria solani. Plant Dis. 2013, 97, 952-960. [CrossRef] [PubMed]

63. Thomas, A.; Langston, D.B.; Stevenson, K.L. Baseline sensitivity and cross-resistance to succinate-dehydrogenase-inhibiting and demethylation-inhibiting fungicides in Didymella bryoniae. Plant Dis. 2012, 96, 979-984. [CrossRef] [PubMed]

64. Miyamoto, T.; Ishii, H.; Seko, T.; Kobori, S.; Tomita, Y. Occurrence of Corynespora cassiicola isolates resistant to boscalid on cucumber in Ibaraki Prefecture, Japan. Plant Pathol. 2009, 58, 1144-1151. [CrossRef]

65. Mueller, D.S.; Wise, K.A.; Dufault, N.S.; Bradley, C.A.; Chilvers, M.I. Introduction. In Fungicides for Field Crops, 1st ed.; Mueller, D.S., Wise, K.A., Dufault, N.S., Bradley, C.A., Chilvers, M.I., Eds.; American Phytopathological Society (APS Press): St. Paul, MN, USA, 2013; pp. 1-13.

66. Green, E.; Duriatti, A. Sensitivity of Uncinula necator isolates to quinoxyfen: Baseline studies, validation of baseline method, and targeted sensitivity monitoring after several years of commercial use. In Proceedings of the BCPC International Congress Crop Science or Technology 2003, Glasgow, UK, 10-12 November 2003; pp. 163-168.

67. Fernández-Ortuño, D.; Chen, F.; Schnabel, G. Resistance to cyprodinil and lack of fludioxonil resistance in Botrytis cinerea isolates from strawberry in North and South Carolina. Plant Dis. 2013, 97, 81-85. [CrossRef]

68. Forster, H.; Su, H.; Vilchez, M.; Gubler, W.; Adaskaveg, J.E. Non-persistent captan and fenhexamid-resistance in Botrytis cinerea populations in California strawberries. Phytopathology 2007, 97, S36.

69. Weber, R.W.S. Resistance of Botrytis cinerea to multiple fungicides in northern German small-fruit production. Plant Dis. 2011, 95, 1263-1269. [CrossRef] [PubMed]

70. Cherrad, S.; Hernandez, C.; Vacher, S.; Steva, H. First detection of boscalid-resistant strains of Erysiphe necator in French vineyards: Biological and molecular characterization. In Modern Fungicides and Antifungal Compounds; Deising, H.B., Fraaije, B., Mehl, A., Oerke, E.C., Sierotzki, H., Stammler, G., Eds.; Deutsche Phytomedizinische Gesellschaft: Braunschweig, Germany, 2017; Volume 8, pp. 211-216.

71. Cherrad, S.; Charnay, A.; Hernandez, C.; Steva, H.; Belbahri, L.; Vacher, S. Emergence of boscalid-resistant strains of Erysiphe necator in French vineyards. Microbiol. Res. 2018, 216, 79-84. [CrossRef] 
72. Mair, W.; Lopez-Ruiz, F.; Stammler, G.; Clark, W.; Burnett, F.; Hollomon, D.; Ishii, H.; Thind, T.S.; Brown, J.K.M.; Fraaije, B.; et al. Proposal for a unified nomenclature for target-site mutations associated with resistance to fungicides. Pest Manag. Sci. 2016, 72, 1449-1459. [CrossRef]

73. Yamashita, M.; Fraaije, B. Non-target site SDHI resistance is present as standing genetic variation in field populations of Zymoseptoria tritici. Pest Manag. Sci. 2018, 74, 672-681. [CrossRef]

74. Scalliet, G.; Bowler, J.; Luksch, T.; Kirchhofer-Allan, L.; Steinhauer, D.; Ward, K.; Niklaus, M.; Verras, A.; Csukai, M.; Daina, A.; et al. Mutagenesis and functional studies with Succinate DehydrogenaseInhibitors in the wheat pathogen Mycosphaerella graminicola. PLoS ONE 2012, 7, e35429. [CrossRef] [PubMed]

75. Stammler, G.A.; Wolf, A.; Klaach, K. Mechanisms of resistance. Respiration inhibitors: Complex II. In Fungicide Resistance in Plant Pathogens; Ishii, H., Hollomon, D.W., Eds.; Springer: Tokyo, Japan, 2015; pp. 104-117.

76. Popko, J.T., Jr.; Sang, H.; Lee, J.; Yamada, T.; Hoshino, Y.; Jung, G. Resistance of Sclerotinia homoeocarpa field isolates to succinate dehydrogenase inhibitor fungicides. Plant Ducky Dis. 2018, 102, 2625-2631. [CrossRef] [PubMed]

77. Roohparvar, R.; Waard, M.A.D.; Kema, G.H.J.; Zwiers, L.H. MgMfs1, a major facilitator superfamily transporter from the fungal wheat pathogen Mycosphaerella graminicola, is a strong protectant against natural toxic compounds and fungicides. Fungal Genet. Biol. 2007, 44, 378-388. [CrossRef]

78. Omrane, S.; Audéon, C.; Ignace, A.; Duplaix, C.; Fillinger, S. Plasticity of the MFS1 promoter leads to multidrug resistance in the wheat pathogen Zymoseptoria tritici. mSphere 2017, 2, e00393-17. [CrossRef] [PubMed]

79. Sang, H.; Hulvey, J.; Popko, J.T., Jr.; Lopes, J.; Swaminathan, A.; Chang, T.; Jung, G. A pleiotropic drug resistance transporter is involved in reduced sensitivity to multiple fungicide classes in Sclerotinia homoeocarpa (F.T. Bennett). Mol. Plant Pathol. 2015, 16, 251-261. [CrossRef]

80. Sang, H.; Hulvey, J.P.; Green, R.; Xu, H.; Im, J.; Chang, T.; Jung, G. A xenobiotic detoxification pathway through transcriptional regulation in filamentous fungi. mBio 2018, 9, e00457-18. [CrossRef]

81. Hu, W.; Yan, L.; Ma, Z. Cloning and expression analysis of a putative ABC transporter gene $B g A B C 1$ from the biotrophic pathogenic fungus Blumeria graminis f. sp. tritici. J. Phytopathol. 2008, 156, 120-124. [CrossRef]

82. Avenot, H.F.; Michailides, T.J. Progress in understanding molecular mechanisms and evolution of resistance to succinate dehydrogenase inhibiting (SDHI) fungicides in phytopathogenic fungi. Crop Prot. 2010, 29, 643-651. [CrossRef]

83. Billard, A.; Fillinger, S.; Leroux, P.; Lachaise, H.; Beffa, R.; Debieu, D. Strong resistance to the fungicide fenhexamid entails a fitness cost in Botrytis cinerea, as shown by comparisons of isogenic isolates. Pest Manag Sci. 2012, 68, 684-691. [CrossRef]

84. Bauske, M.J.; Gudmestad, N.C. Parasitic fitness of fungicide-resistant and -sensitive isolates of Alternaria solani. Plant Dis. 2018, 102, 666-673. [CrossRef]

85. Vielba-Fernández, A.; Polonio, Á.; Ruiz-Jiménez, L.; de Vicente, A.; Pérez-García, A.; Fernández-Ortuño, D. Fungicide resistance in powdery mildew fungi. Microorganisms 2020, 8, 1431. [CrossRef]

86. Miyamoto, T.; Hayashi, K.; Ogawara, T. First report of the occurrence of multiple resistance to Flutianil and Pyriofenone in field isolates of Podosphaera xanthii, the causal fungus of cucumber powdery mildew. Eur. J. Plant Pathol. 2020, 156, 953-963. [CrossRef]

87. McGrath, M.T. First report of resistance to quinoxyfen in Podosphaera xanthii, causal agent of cucurbit powdery mildew, in the United States. Plant Health Prog. 2017, 18, 94. [CrossRef]

88. Sedláková, B.; Lebeda, A.; Jerabkova, H.; Paulik, R.; Vajdova, M. Resistance to fenarimol, dinocap, benomyl, thiophanate-methyl and azoxystrobin in cucurbit powdery mildew populations in the Czech Republic. Acta Fytotech. Zootech. 2012, 15, 46-49.

89. Pirondi, A.; Nanni, I.M.; Brunelli, A.; Collina, M. First report of resistance to cyflufenamid in Podosphaera xanthii, causal agent of powdery mildew, from melon and zucchini fields in Italy. Plant Dis. 2014, 98, 1581. [CrossRef]

90. Farm to Fork Strategy. For a Fair, Healthy and Environmentally Friendly Food System. Available online: https: / / ec.europa.eu/ food/system/files/2020-05/f2f_action-plan_2020_strategy-info_en.pdf (accessed on 16 June 2021). 